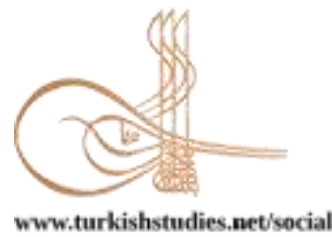

Turkish Studies - Social Sciences

eISSN: $2667-5617$

\title{
Bilgi İletişiminde Fotoğrafın Gücü ve Sultan II. Abdülhamid Han Albümlerinin Konu ve Araştırmacı Profillerinin Analizi
}

\author{
The Power of Photography in Information Communication and Analysis of Subject-Matter and \\ Researcher Profiles of Sultan Abdülhamid II. Khan Albums
}

\author{
Pervin Bezirci*
}

\begin{abstract}
Following the invention of the printing press, just as how it became possible for the written information to be shared by large audiances, the invention of the photograph also allowed the spread and sharing of visual information. Following the invention of photography, as a result of which important changes in social life took place, writing and technical images became complementary and inevitable communication tools for information. The possibilities of telling and questioning the photographic image and thinking that it reflects only the truth made it a privilege. This idea has turned photograph into a historical document. Throughout history, photography has been used as a tool of perception, persuasion and evidence, and over time it has been included in archives as a valuable visual material and a document. In this study, the reign of Abdülhamid II, during which The Y1ldız Palace Photography Collection, was formed by the use of the photograph as a document, a detection method, promotion and a communication tool which at the same time gave rise to The Yildiz Palace Photography Collection itself, has been taken up. In order to be able to reveal how these photographs, in Abdülhamid II. Albums, housed in Rare Works Library of İstanbul University still in use as information and document tools reaching today from the past, have been analyzed with numerical data in terms of topics, qualities and researcher profiles. At the same time, from the standpoint of archive materials and visual values, since it has become important to improve the accessibility to as well as the identification and preservation of photographs, The Abdülhamid II Photo Albums Project has been put forward briefly via the contribution of the Project to information communication which has made it easier to facilitate access to photographs.
\end{abstract}

Structured Abstract: Photography has been used as a surveillance instrument to enable inspection from its conception up until the current day. Photography, like other technological phenomena, has been directed to meet the needs of the administrations and the dominant conversation within the framework of the conditions in which it was set off. It is offered to the service of different fields of power or sciences as detective, proving, classifying mechanisms. As the area of use expands and its function increases, photography has turned into recording and propaganda materials that make it easier to control more and more professionals in the public sphere. Thus, photographs have become important documents and assets for social sciences as an indicator of

\footnotetext{
* Dr, İstanbul Üniversitesi Kütüphane ve Dokümantasyon Daire Başkanı

Dr., Istanbul University, Head of Library and Documentation

ORCID 0000-0002-2569-4956

pervinb@istanbul.edu.tr

Cite as/ Atıf: Bezirci, P. (2020). Bilgi iletișiminde fotoğrafın gücü ve Sultan II. Abdülhamid han albümlerinin konu ve araştırmac1 profillerinin analizi. Turkish Studies - Social, 15(4), 1753-1778.
} https://dx.doi.org/10.29228/TurkishStudies.43242

Received/Geliş: 29 April/Nisan 2020

Accepted/Kabul: 20 June/Haziran 2020

Copyright $($ INTAC LTD, Turkey

Checked by plagiarism software

Published/Yayın: 25 June/Haziran 2020

CC BY-NC 4.0 
social transformations that sprouted and continued in the 19th century. Photographic images have become instruments in the construction of a social memory in the years to come and photographic images about historical events have made the cases legitimate in the eyes of the citizens.

In this context, during the reign of Abdulhamid II. Yıldız Palace Photography Collection was established over time with the instigation of photography as a document, detection, promotion and communication mechanism. As a sultan who was open to the technological blossomings of the period during his sovereignity, Sultan Abdülhamid II. Khan's photograph archive created by himself is an important and valuable cultural heritage of the 1800s. These albums, defined as the largest visual archive in the world in the 19th century and presenting the last photographs of the ruling systems in various countries of the world are important apertures for future projections. In addition to Ottoman History, Abdülhamid II Collection, a infrequent work -so to speak- in itself, offers the opportunity to follow and document social upshots in social, political, geographical, artistic and many other features and throw light on history with its towering document value. These albums, having a wide range of utilization, portray the technology, science, art and aesthetic understanding of the period, as well as their outlook on information, document and archival pursuit.

The Y1ldiz Palace Library Collection including these valuable asset works, was founded in 1924 by and upon the order of M.K. Atatürk, it was transferred to the Darülfünun Library, today's İstanbul University's Rare Works Library, located in the Medrese-t-ül Kuzat (Former Kadi School) building. Currently in the İstanbul University Rare Works Library. Abdülhamid II Khan Albums were analyzed within the scope of this analysis in order to reveal how these photographs moved from past to present have been used as information and document instruments and analyzed with numerical data in terms of researcher profiles using photographs, qualities and photographs. According to the results of this research; photography topics in Y1ldiz Albums Collection have a wide range of content, from civil architecture to religious architecture, to official buildings to squares, to complexes to bridges, to caravanserais to schools, and to hospitals to roads. The regime in various countries of the world has always had an important visual implement for examining the system, social and political structures. Some of the photographs include cities, natural beauties, leaders, palaces and various industrial products, museums and works of art in America, Europe and some Far Eastern countries, especially Japan. as the subject matter. In terms of the importance of religions and civilizations in history, it is understood from the content and numbers of photographs that Ottoman lands and especially İstanbul were the focus of most European photographers Abdülhamid II album Collection is also an important source of work from the standpoint of photographic art. When the albums are analyzed in terms of photographers, itcan be seen that the period reflects the viewpoints of the most talented and famous photographers.

Furthermore, Y1ldız Palace Photography Collection is not only a cultural treasure but also an important data source in terms of different branches of science and arts since it contains images having to do with many different fields (history, art, architecture, geography, education, literature, etc.) and it appears to be a resource for various scientific studies. Albums have been considered from different aspects and various studies such as films, documentaries, print-outs, academic publications, and exhibitions involving different disciplines have been carried out.

It is of strategic significance to ensure the continuity of these precious photographs, due to their important archival material characteristics as historical memories. For photographs with archival materials of evident value, it becomes essential to define and maintain archive applications. In addition, it is highlighted in this analysis that it is important to improve the accessibility to photographs taking into consideration archive material properties and visual values. As outlined in the analysis as a sample application, with the aim of creating digital copies of the Album Collection to be used by the researchers by providing the preservation of the conditions of the Album Collection, ensuring that the researchers can access the photos quickly and safely, Abdülhamid II. Khan Yildiz Albums Project has been carried out under the auspices of the Presidency, with the cooperation of İstanbul University Rector's Office and National Palaces. İstanbul University. Within the scope of the Abdülhamid II Photo Albums Project, it is seen that the historical document photographs are brought together with the researcher and information communication by digitizing valuable photographs, conducting qualified bibliographic imprint studies and providing electronic access.

Transferring the works of cultural heritage value to a digital medium and ensuring their durability has been a kind of insurance to protect the content. Sultan Abdülhamid II. Photo Albums Project has created a new resource that sheds light on scientific studies. As a result of which digitizing this precious visual treasure, making bibliographic tags and making it all accessible in an electronic medium. In addition to transferring the

Turkish Studies - Social, 15(4) 
collection to future generations, protecting the cultural heritage value and providing digital access, the opportunity to read, interpret and discover the social, cultural, economic and political history of the period through the photo collection has been provided to researchers independent of time and location making contributions to the scientific studies.

Keywords: Information and Document, Photograph, Communication, Abdulhamid II Photograph Collection, İstanbul University's Rare Works Library

Öz: Matbaanın bulunması ile beraber nasıl yazılı bilgi geniş kitlelerle paylaşılabilir hale geldiyse, fotoğrafın bulunuşu da görsel bilginin yaygınlaşması ve paylaşılmasına olanak sağlamıştır. Fotoğrafın icadından sonra toplumsal yaşamdaki önemli değişiklikler sonucu yazı ve teknik görüntüler birbirini tamamlayan vazgeçilmez bilgi iletişim araçları halini almıştır. Fotoğrafik görüntünün yaşamı anlatma, sorgulama olanakları ve sadece gerçeği yansıttığının düşünülmesi onu ayrıcalıklı kılmıştır. Bu düşünce fotoğrafa tarihi belge niteliği kazandırmıştır. Tarih boyunca fotoğraf bir algı yönetme, ikna ve kanıt aracı olarak kullanılmış ve zamanla değerli görsel malzemeler ve belge olarak arşivlerde yer almıştır. Bu çalışmada, fotoğrafın yaygın ve etkin kullanıldığ 1 tarihi bir süreç olan II. Abdülhamid döneminde, fotoğrafın belge, tespit, tanıtım ve iletişim aracı olarak kullanılmaya başlanması ile oluşan Yıldız Sarayı Fotoğraf Koleksiyonu ele alınmaktadır. Geçmişten günümüze taşınan bu fotoğrafların bilgi ve belge aracı olarak halen nasıl kullanıldığının ortaya konulması amac1yla, İstanbul Üniversitesi Nadir Eserler Kütüphanesi’nde bulunan II. Abdülhamid Albümleri konuları, nitelikleri ve araştırmacı profilleri açısından sayısal verilerle analiz edilmektedir. Aynı zamanda, arşiv malzemesi ve görsel değerleri bakımından fotoğrafların, tanımlama ve koruma yanı sıra erişim koşullarının da iyileştirilmesi önemli hale geldiğinden, konu ile ilgili olarak İstanbul Üniversitesi II. Abdülhamid Fotoğraf Albümleri Projesi kısaca anlatılarak, Projenin fotoğraf erişimini kolaylaştırarak bilgi iletişimine katkısı ortaya konulmaktadir.

Anahtar Kelimeler: Bilgi ve Belge, Fotoğraf, İletişim, II. Abdülhamid Fotoğraf Koleksiyonu, İstanbul Üniversitesi Nadir Eserler Kütüphanesi

\section{Giriş}

İnsanoğlu, yaşadığı değişim süreçlerinde, kendini ve yaşamını etkileyen gerçeklikleri her zaman kaydetme ve geleceğe aktarma eğiliminde olmuştur. Bu sebepledir ki, iletişim teknolojileri insanlık tarihi boyunca insan yaşamı ve insanın yarattığı kültür üzerinde önemli etkiler yaratmıştır. "İcadından itibaren fotoğrafın görüntü oluşturmada barındırdığı fiziksel ve kimyasal süreç, onu, gerçekliği sunmada diğer görsel sanatlardan üstün tutmuştur. Fotoğrafin nesnelliği görüntüye hiçbir resim ürününde bulunmayan inandırma gücü” vermiştir (Satkın, 2014:7-8). Bu yüzden, tarih boyunca, sanatsal yönüyle birlikte sosyal ve siyasal alanda bir iletişim vasitası haline gelen fotoğrafçılık, "Osmanlı dünyasında da oldukça geniş bir tatbikat sahası ve Saray gibi bir hami bulmuştur. Bilhassa II. Abdülhamid fotoğrafı, tespit ve tanıma vasıtası olması yanı sıra bir tanıtma aracı olarak da kullanmıştır" (Yılmaz, 2009:30).

İşte bu sebeple, bu çalışmada fotoğrafin yaygın ve etkin kullanıldığı tarihi bir süreç olan II. Abdülhamid döneminde, fotoğrafın belge, tespit, tanıtım ve iletişim aracı olarak kullanılmaya başlanması ile oluşan Yıldız Sarayı Fotoğraf Koleksiyonu ele alınmaktadır. Dönemin teknolojik gelişmelerine açık bir padişah olarak, Sultan II. Abdülhamid Han'ın oluşturduğu fotoğraf arşivi, 1800'lü yıllara ait önemli ve nadide bir kültür mirasıdır. Geçmişten günümüze taşınan bu fotoğrafların bilgi ve belge aracı olarak halen nasıl kullanıldığının ortaya konulması amaciyla, bu çalışmada İstanbul Üniversitesi (ï̈) Nadir Eserler Kütüphanesi’nde bulunan II. Abdülhamid Albümleri incelenmiştir. Albümler fotoğraf konuları, nitelikleri ve fotoğrafları kullanan araştırmacı profilleri açısından değerlendirilmekte ve sayısal verilerle analiz edilmektedir. 
Fotoğraflar, tarihi olayların kanıtını sağlayan birer bellek olarak önemli bir arşiv malzemesi özelliği teşkil ettikleri için arşivleme uygulaması açısından da özel bir yere sahiptirler. Bu nedenle devamlılıklarını sağlamanın, stratejik bir önemi vardır. Hayatın gerçeklerine ayna tutan, kanıtsal değere sahip arşiv malzemeleri olan fotoğraflar için arşiv uygulamalarının, özellikle tanımlama ve muhafaza etme hususlarının yerine getirilmesi büyük önem arz etmektedir (Şentürk, 2013, s.630) Arşiv malzemesi ve görsel değerleri bakımından fotoğrafların, tanımlama ve koruma yanı sıra erişim koşullarının iyileştirilmesinin de önemli olduğu bu çalışmada vurgulanmaktadır. Konu hakkında bir uygulama örneği olarak, İstanbul Üniversitesi II. Abdülhamid Fotoğraf Albümleri Projesi anlatılmaktadır. Proje kapsamında, değerli fotoğrafların dijitalleştirilmesi, nitelikli bibliyografik künye çalışmalarının yapılması ve elektronik ortamdan erişiminin sağlanması yoluyla, tarihi belge niteliğindeki fotoğrafların araştırmacı ile buluşturulması ve bilgi iletişimine nasıl katkı sağlandığı ortaya konulmaktadır.

\section{Bilgi İletişim Aracı Olarak Fotoğraf ve Sultan II. Abdülhamid}

1839'da bulunduğu ilan edilen ve görüntülerin mekanik olarak yeniden üretiminin ilki olan fotoğrafın icadı, insanların doğumdan itibaren dünyayı tanıma biçimi olan görsel olarak öğrenmenin bilgi formuna dönüştürülebilmesine, yaygınlaşmasına ve kitlelerce paylaşımına olanak tanımıştır (Arıcan, 2007:423). Fotoğrafın geçmişinden günümüze kadar olan gelişimi incelendiğinde, hep belgelemek ve kayıt altına almak amacının var olduğu görülmektedir. Fotoğraf iletişim gücü sayesinde, kelimelerin aktaramayacağı bir mesajı, sanatsal olarak güçlü bir şekilde iletebilen evrensel bir araçtır (Ballenger, 2014:1). Fotoğraflar, kitleler ile iletişim kurmak için olduğu kadar bilginin, haberin ve verilmek istenen mesajın bireysel ve toplumsal bellekte saklanmasında da önemli ve etkin araçlardır (Gezgin, 1994:29). Fotoğrafın zamanı dondurma gücü yanı sıra, verilmek istenen mesajı yayma özelliği sayesinde oluşan, zamanı hızlandırma gücünden dolayı, toplumlara köklü sosyal bir etkisinin olduğu düşünülmektedir (Ballenger, 2014:23). Fotoğrafi kendi bakış açısı ve yeteneği ile objektifinden yansıtan fotoğrafçı bir tanık ve gözlemci rolünün yanı sıra toplumun siyasal, ekonomik ve sosyal konularını araştırıcı rolüne de sahiptir (Amar, 2009:41). Dolayısıyla, fotoğrafin görünmeyen dünyayı gösterme gibi bir gücü oluşmaktadır ki bu sayede insanlar sosyal konuları belgelendirebilir, fotoğrafın sağladığı bilgi ile toplum bilincini artırabilir ve bireylere harekete geçmek için ilham verebilir (Ozanne,2013:48).

Fotoğrafin bütün bu özelliklerinin yaygın ve etkin kullanıldığı tarihi bir süreç olan II. Abdülhamid döneminde (1876-1908) Sultan, fotoğrafı saltanatı sırasında kullanmasıyla ünlü olduğundan 'fotoğrafin sultanı' olarak da anılmaktadır. Fotoğraf, Sultan II. Abdülhamid için kapalı bir şekilde yaşadığı Yıldız Sarayı'nın yüksek duvarları ile dünya arasında kurduğu bir iletişim köprüsüydü (Bayhan, 2009:15). II. Abdülhamid'in “Her resim bir fikirdir. Bir resim yüz sayfalık yazı ile ifade olunamayacak siyasi, hissi manalart telkin eder. Onun için ben, tahrir-i mündericattan (yazılı belgelerden) ziyade, resimlerden istifade ederim" sözü fotoğrafa olan bakış açısı ve fotoğrafin iletişim gücüne yaklaşımını göstermektedir (Dördüncü, 2006:13; Waley,1991:114).

"Bugün olduğu gibi geçmişte de teknolojik gelişmeler ve onların yaygınlaşması kurumların, mevcut iktidarın işleyişiyle ilgiliydi ve bu teknolojik araçların kabulü güncel ihtiyaçlara bağlı olarak yönlendirilmekteydi" (Toksoy, 2019:494). II. Abdülhamid de iktidarı döneminde teknolojiyi ihtiyaçlara göre yönlendirmiştir. II. Abdülhamid, devrin şartlarının getirdiği hassas dengeler ve güvenlik endişesi dolayısıyla yurt içi gezilerde bile bulunamamıştır. Ancak memleketin her köşesini takip ettiği, yapılan her binanın, her okulun, her askeri kıtanın, devlet daireleri ve personelin, hapishanelerdeki mahkumların dahi fotoğraflarını çektirdiği (Dördüncü, 2006:7), bu fotoğrafların "Saray tarafından istihbarattan envanter çıarmaya, muharebe safahatının takibinden hüviyet tespitine, çeşitli faaliyetlerin raporlarında tevsik ve tanıtım faaliyetine kadar pek çok sahada kullanıldı̆̆ı"(Yılmaz, 2009:44) bilinmektedir. "II. Abdülhamid, Osmanlı coğrafyası dışındaki ülkelerden de fotoğraflara ulaşma gayreti içerisinde olmuştur”(Çiçek, 2018:45484). Bu yaklaşımın 
neticesi olarak Yıldız Sarayı Fotoğraf Koleksiyonu oluşmuştur. Yıldız Albümleri gerek Osmanlı coğrafyasının yüzlerce farklı kentinin görüntülerini saklaması gerekse Osmanlı dışındaki Moskova, Londra, Paris gibi kentlerin fotoğraflarını ihtiva etmesi ile çok zengin bir şehir kültürü ansiklopedisi hüviyeti de taşımaktadır. "Devrin usta fotoğrafçılarının çektiği görüntüler, II. Abdülhamid döneminde (1876-1908) İstanbul ve Anadolu'nun her köşesine ait bilgiler vermesinin yanında, Japonya, Çin, Orta Asya, Rusya, Hindistan, Orta Doğu, Balkanlar, Avrupa ve Amerika Birleşik Devletlerinin önemli şehirleriyle ilgili bilgiler vermektedir" (Dördüncü, 2006:7-14 ). Fotoğrafın 1839'da teknik olarak tescilinden sonra, Abdülhamid devrine kadar geçen süre sadece 37 yıldır. Fotoğraf, sultan olarak varlığını sürdürdüğü dönemde çok büyük bir gelişme kaydetmiştir. İstanbul'da fotoğrafçılığın ilk yılları, stüdyo fotoğrafçılığının altın dönemi olarak yaşanmıştır (Bayhan, 2009:13).

Fotoğrafın belli bir ideolojiyi oluşturmak ve yaymak adına araç olarak kullanımının yaygınlığı, bireylerin kanaatlerini yönlendirme konusundaki etkisi, onun öteki görüntü oluşturma tekniklerinden farklı bir yanıdır (Toksoy, 2019:501). Bu özelliği ile fotoğraf, Sultan II. Abdülhamid devrinde tespit ve tanıma vasıtası olmasının yanı sıra bir tanıtma aracı olarak da kullanılmıştır (Yılmaz, 2009:30). Fotoğraf düzenlemelerinin çoğunluğu Batı'nın ilgisini çekecek şekilde yapılmıştır. İlk fotoğraflarda Osmanlı topraklarını hiç görmeyen ve bir zamanların muhteşem devletini merak eden Batılllar için "ilginç olan ne varsa çekilmeli" düşüncesiyle sokakta çalışan esnaflardan, Osmanlı topraklarında yetiştirilen hayvan türlerinden, tarihi eserlere, okul ve hastanelere kadar hemen her alanda fotoğraf çekilmiştir (Dördüncü, 2006:12).

Fotoğrafların hatırlamaya ilişkin gücü, onların, tarihin inşa sürecinde oynayacakları önemli rolün de göstergesidir. Özellikle de bazı tarihsel olayları hatırlatan nitelikteki fotoğraflar, geçmiş ile köprü kurulmasında etkili olurken, söylemlerden daha yoğun olarak hafızalarda yer edinecektir. Başka bir deyişle 'ortak hafıza' oluşturmak için kullanılan fotoğraflar, ideolojilerin tarihi nasıl inşa etmek istedikleri meselesi olabilmektedir (Toksoy, 2019:503). II. Abdülhamid'in devletler aras1 ilişkiler ve siyasi arenada fotoğrafi kullanması tam da bu etkiyi amaçlamıştır. Sultan II. Abdülhamid "Fotoğrafı saltanatı için bir propaganda malzemesi olarak kullanmış ve yabancı ülkelere dönem dönem Osmanlı'nın kültür yapısını ve gelişmelerini sergileyen özenle hazırlanmış fotoğraf albümleri gönderilmiştir" (Bayhan, 2009:15). Sultan II. Abdülhamid, "başta Amerikan Kongre Kütüphanesi ve İngiltere Britanya Müzesi Kütüphanesi olmak üzere” (Yılmaz, 2009:31) çeşitli ülkelere ve şahıslara, Osmanlı ülkesini tanıtmak amacıyla hediye albümler göndermiştir.

"Fotoğraflarının belge olma iddiası, gerçeğin belgeleri olmalarından çok toplumsal hafizanın şekillenmesinde üstlendikleri yargı oluşturma rolleriyle açıklanabilir. Başka bir deyişle bu fotoğraflar egemenlerin bellek siyasetinin araçlarına dönüşürler” (Toksoy, 2019:503). Nitekim, 19. yüzyılın sonlarında Osmanlı, kendisini dünya devletlerine ilerici bir anlayışa sahip olarak sunmak için hesaplı bir çaba göstermiş ve dünya sahnesinde kendisini teknolojik ve sosyal olarak eşit bir oyuncu olarak göstermeyi amaçlayan politikalar uygulamıştır. Modern sanat formları olarak fotoğraf, imparatorluğun gerçekleşmekte olan modernizasyonunu yayınlamanın ve büyük bir güç olarak statü iddiasını meşrulaştırmanın mükemmel bir yoluydu. II. Abdülhamid fotoğraf koleksiyonu ilk olarak 1893'te Osmanlı padişahı tarafindan ABD'ye hediye olarak verilmiştir ve şimdi Kongre Kütüphanesi'ndeki Baskılar ve Fotoğraflar Bölümünde yer almaktadır. 1819 fotoğraf içeren toplam elli bir albümde Osmanlı dönemine ait sanayi, askeri ve eğitim projeleri yer almaktadır (Greene,2010:1; Waley,1991:112). "Sultan Abdülhamid bu albümlerden yalnız ABD'ye değil İngiltere, Almanya ve Japonya'ya da göndermiştir" (Bayhan, 2009:15). Yurtdışına gönderilen albümlerin özelikle ebatları ve süslemeleri dikkat çekicidir. Ebatları daha kalın ve büyük, kapak süslemeleri ise diğer albümlerden daha fazladır. Osmanlı Arması, Türk bayrağı ve padişah tuğraları ile süslenmiştir. Albümler Fransızca alt yazılar ile hazırlanmış, bazılarında yabancı diller yanı sıra Osmanlıca ibarelerde yer almaktadır (Y1lmaz, 2009:14). 


\section{Sultan II. Abdülhamid Albümlerinin İstanbul Üniversitesi Nadir Eserler Kütüphanesi'ne Devri}

“M. Kemal Atatürk ve bazı vekillerin imzasını taşıyan, Yıldız Sarayı Kütüphanesi'ndeki yayınların Darülfünun'a devri hakkında 1.6.1924 tarih ve 565 sayll Heyet-i Vekile kararı uyarınca, Ylldız Sarayı Kütüphanesi koleksiyonu Medrese-t-ül Kuzat (Kadı Okulu) binasında bulunan Darülfünun Kütüphanesi'ne, İsmail Hakkı Baltacıoğlu Rektörlügü döneminde nakledilmiştir. Yıldız Sarayı Kütüphanesi 'nin Darülfünun'a devredilmesi, mevcut dermeye müzelik değer taşıyan eserlerin dahil olmasını ve koleksiyonun zenginleşmesini sağlamıştır”'(Şenalp, 1998:12-13; Bezirci, 2020:46). "Yı1dız Kütüphanesi’nin Darülfünun'a devredilmesi sürecinin, Darülfünun Kütüphanesi'nin modern bir kütüphane olarak düzenlenmesine yönelik çalışmalarla hemen hemen aynı döneme rastlaması, koleksiyonun modern kütüphanecilik anlayışına göre düzenlenmesini sağladığı gibi bugünkü İstanbul Üniversitesi Nadir Eserler Kütüphanesi'nin de sağlam temeller üzerinde kurulmasını sağlamıştır" (Atasoy, 2015:26; Bezirci, 2020:46 ).

Nadir Eserler Kütüphanesi (NEK), Türk toplumunun tarihi, siyasi, kültürel ve sosyal hayatına 1şık tutacak nitelikte seçkin ve çok değerli yazma ve nadir eser örneklerini bünyesinde barındırmaktadır. NEK koleksiyonunda 2019 yılı sayım sonuçlarına göre toplam 102.833 adet eser (Türkçe, Arapça, Farsça, Latince ve diğer dillerdeki basma ve yazma kitap, dergi, gazete, albüm, pafta ve rulo haritalar, nota, plak, hat ve levhalar, tablolar, mobilyalar, porselen ve cam eşyalar, yazı araçları ile müzelik değer taşıyan parçalar) bulunmaktadır.

"Dünya çapında ilgi gören, dünyanın en zengin ve önemli görsel hazinelerinden biri olan Yıldız Albümleri yanı sıra koleksiyonda; 1924 yılında İstanbul Üniversitesi Kütüphanesi'ne devredilen, Sultan II. Abdülhamid'in Yıldız Sarayı'nda kurduğu zengin kütüphanesine ait; harita ve planlar, müzik notaları, Avrupa nadir eserler, matbu eserler, Türkçe, Arapça ve Farsça ve diğer dillerdeki yazmalar, süreli yayınlar, gazeteler, objeler ve mobilyalardan oluşan toplam 27.783 adet eser bulunmaktadır, Ayrıca, Rıza Paşa, Halis Efendi, Mollazade İbrahim Bey, Hakkı Paşa, Şevki Paşa ve İbn'ül Emin Mahmud Kemal İnal'ın eserleri de yer almaktadır.

19. yüzyıla ait dünyanın en büyük görsel arşivi olarak tanımlanan, Sultan II. Abdülhamid döneminde çekilen fotoğraflardan oluşan Yıldız Fotoğraf Koleksiyonu, Nadir Eserler Kütüphanesi'nde özenli koşullarda muhafaza edilerek hizmete sunulmaktadır. Koleksiyon, 918 adet albüm ve bunların içinde yer alan 36.585 adet fotoğraftan oluşmaktadır ve yakın tarihimiz açısından paha biçilemez hazine niteliğinde önemli bir kaynaktır" (Bezirci, 2020:113-114).

\section{Sultan II. Abdülhamid Albümlerinin Konuları ve Nitelikleri}

Her biri özenle saklanmış, ciltlenmiş ve yakutlarla, zebercetlerle bezeli sandukalarda arşive kaldırılmış, dönemin teknolojik gelişmelerine açık bir padişah olarak, Sultan II. Abdülhamid Han'ın oluşturduğu bu değerli fotoğraf koleksiyonu, 1800'lü yıllara ait önemli ve nadide bir kültür mirasıdır. 19. yüzyıla ait dünyanın en büyük görsel arşivi olarak tanımlanabilecek, dünyanın çeşitli ülkelerinde rejim, sistem ya da sosyal ve siyasal yapıların değişmezden önceki son fotoğraflarını toplu halde sunan fotoğrafları günümüze ulaştıran bu albümler, günümüzden geleceğe yapılacak projeksiyonlar için önemli pencerelerdir. Bu fotoğraflar, sadece İstanbul ya da Osmanlı topraklarının değil, neredeyse tüm dünyanın eski bir tapusu niteliğindedir (Atasoy, 2009, s.22-23; Atasoy, 2007, s.8-9).

Yıldız Albüm Koleksiyonu'ndaki fotoğraf konuları, sivil mimariden dini mimariye, resmi binalardan meydanlara, külliyelerden köprülere, kervansaraylardan mekteplere ve hastanelerden yollara kadar çok geniş bir içeriğe sahiptir (Ak,2020). "Başta İstanbul olmak üzere, imparatorluğun diğer büyük kentlerinden manzaralar, günlük hayat kesitleri (örnek foto 1,2), meslekler, imar hareketleri ayrı dönemlerde çeşitli fotoğrafçılar tarafından çekilmiş ve sultana ulaştırılmıştır (Bayhan, 2009:15). 


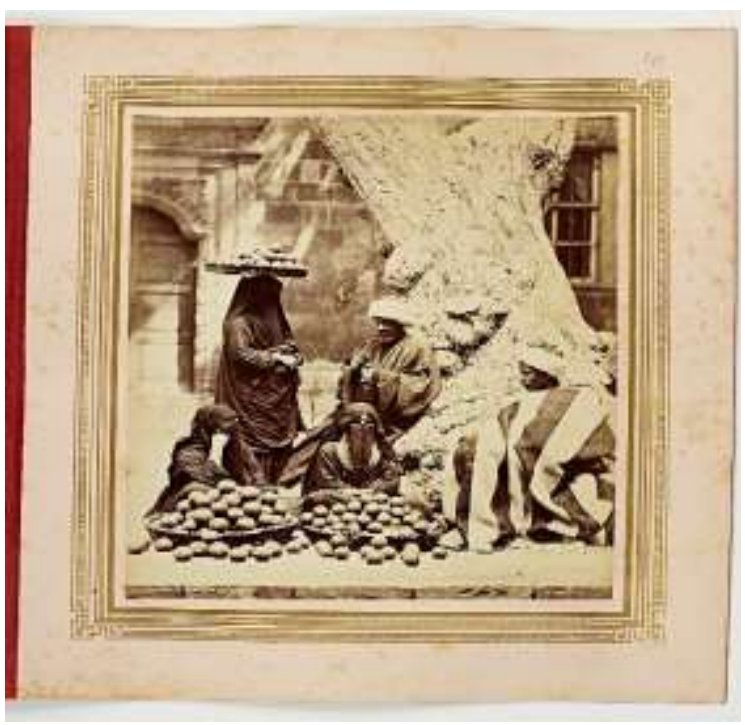

\section{$91263 / 41$}

Fotoğrafçı: Béchard, Émile.

Fotoğraf adı: Costumes Arabes, Portakal satıcısı.

Fotoğrafin konusu: Arap Kadınlar, Araplar, Misır, Ticaret, Arap kiyafetleri.

Fiziksel özellikler: Siyah-beyaz, 26x20 cm.

Paspartu: Beyaz karton, yaldız baskı cetvellidir, $37 \mathrm{x} 30 \mathrm{~cm}$.

Foto 1. 91263/41, Costumes Arabes, portakal saticis1.

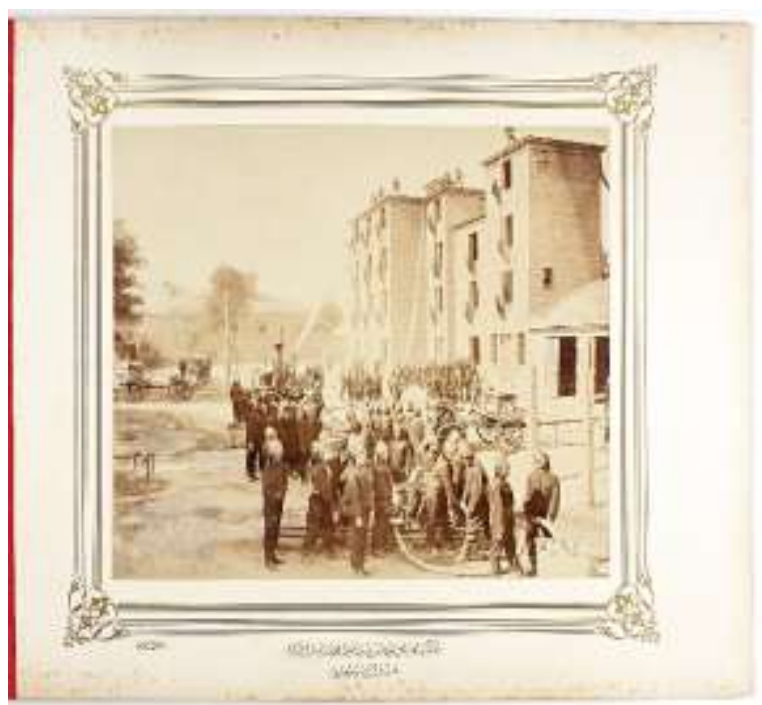

\section{$91019 / 1$}

Fotoğrafçı: Abdullah Fréres.

Fotoğraf adı: Beyoğlu Kışla-i Hümayunu pişgahında itfaiye alayının birinci ve ikinci taburları umera ve zabitanın harika mahsus elbiseleriyle vaziyeti.

Fotoğrafin konusu:1839-1922, İtfaiye teşkilatı, İtfaiyeciler, Yangın söndürme, İtfaiyeci kıyafetleri.

Fiziksel özellikler: Siyah-beyaz, 38x31 cm.

Paspartu : Beyaz karton, 59x47 cm.

Yayın Bilgileri: İstanbul, Abdullah Biraderler

Foto 2. 91019/1, itfaiye teşkilatı

Fotoğrafların bir kısmı Amerika, Avrupa ile başta Japonya olmak üzere bazı Uzakdoğu ülkelerindeki şehir ve tabiat güzelliklerini, sarayları, fabrikaları, gemi, silah ve çeşitli sanayi ürünlerini, din ve devlet büyüklerini, müze ve sanat eserlerini konu olarak alır. Ancak çoğunluğunu, Osmanlı İmparatorluğu topraklarındaki şehirler, adalar, kaleler, köprüler, fabrikalar, gemiler, karakollar, çeşmeler, camiler, türbeler, okullar, hastaneler (örnek foto 3,4), şehir panoramaları, sportif gösteriler, arkeolojik yöreler, törenler, yabancı devlet başkanlarının İstanbul ve Kudüs'ü ziyaretleri, demiryolları, istasyonlar, sergiler, çiftlikler, Osmanlı sarayları, köşkler ve kasırlar, saray mücevherleri, saray tiyatrosu, şehzade ve sultanlar, zabit ve yaverler gibi çok çeşitli konular oluştururlar (Atasoy, 2007: 8-9; Dördüncü, 2006:14). 


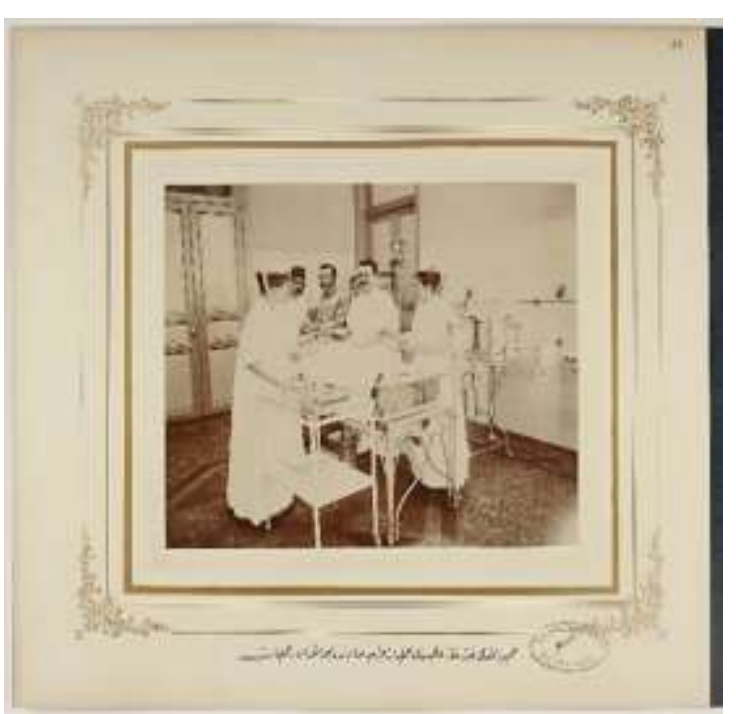

$90609 / 15$

Fotoğrafçı: Fuad.

Fotoğraf adı: Hamidiye Etfal Hastahane-i Alisi'nin ameliyat-1 cerrahiye salonunda icra k1linan bir ameliyat.

Fotoğrafın konusu: Şişli Hamidiye Etfal Eğitim ve Araştırma Hastanesi, Sağlık hizmetleri, Ameliyathane, Hastane mimarisi, Sağlik personeli.

Fiziksel özellikler: Siyah-beyaz, 29x23 cm.

Paspartu ölçüsü: 46x37 cm.

Tarih:1903.

Foto 3. 90609/15, Hamidiye Etfal Hastahane-i Alisi

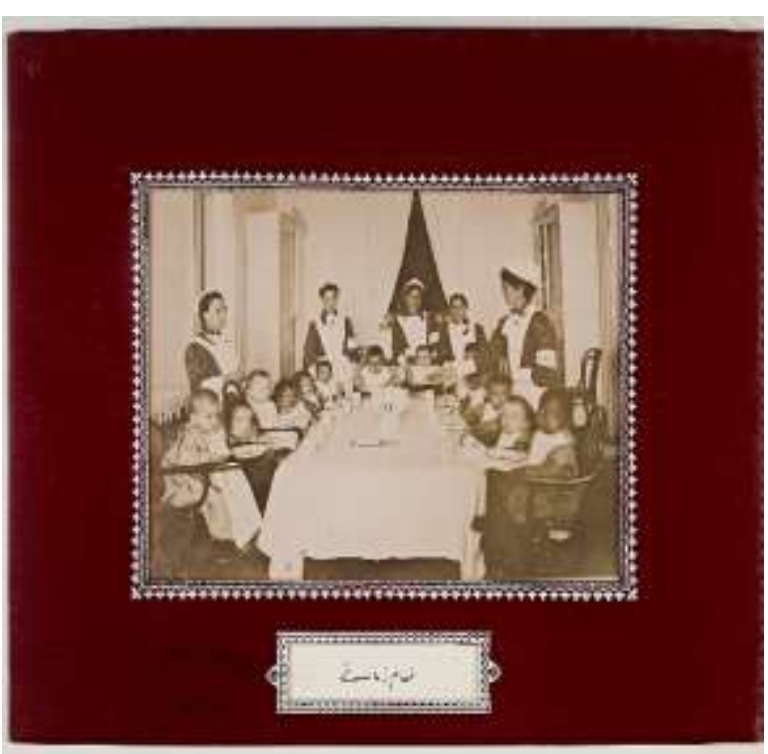

AA90620/1

Fotoğrafç1: Feigenbaurg, S.J.

Fotoğraf adı: Darülaceze İrzâhanesi'nin haricen görünüşü ve etfal.

Fotoğrafin konusu: Darülaceze (İstanbul), Sosyal hizmetler, Yardım kuruluşları, Yetim çocuklar

Fiziksel özellikler: Siyah-beyaz, 22x16 cm.

Paspartu ölçüsü: 36x30 cm.

Foto 4. AA90620/1, Darülaceze İrzâhanesi'nin haricen görünüşü ve etfal.

II. Abdülhamid devri, 1839'dan beri yapılan değişikliklerin bir odak noktasında toplandığ1, Batı fikirlerinin iyice anlaşılmaya başlandığı bir devirdir (Mardin,1985:347; Türköne\&Önder,2011:15). II. Abdülhamid'in otuz üç yıl kaldığı padişahlık döneminde bayındırlık yanında eğitimin yayılmasını sağlayacak tedbirlere de başvurulmuş, modern eğitim bu dönemde yerleşmiştir (Baytal, 2000:28). "Bu dönemde ilkokuldan üniversiteye kadar eğitimin hemen her alanında, günümüz eğitim kurumlarının temellerini oluşturan okullar açılmıştır” (Bezirci, 2019:284). Bu dönemde eğitime verilen önemin fotoğraflara da yansıdığı görülmektedir (örnek foto 5). 


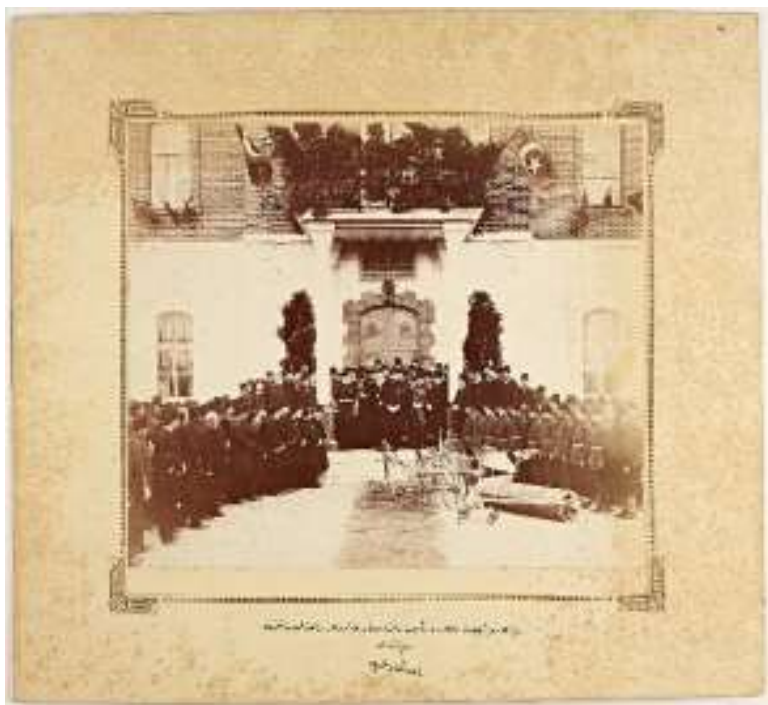

\section{$90852 / 26$}

Fotoğraf adı: Saye-i mehasinvaye-i hazret-i mülükanede tesis ve inşa olunan Hüdavendigar ziraat ameliyat mektebi.

Fotoğrafin konusu: Hüdavendigar Hamidiye Ziraat Ameliyat Mektebi (Bursa), Eğitim, Öğrenciler, Okullar.

Fiziksel özellikler: Siyah-beyaz, değişik ölçülerdedir.

Paspartu: Beyaz ve gri karton, değişik ölçülerdedir.

Tarih: 1891.

Foto 5. 90852/26, Hüdavendigar Hamidiye Ziraat Ameliyat Mektebi (Bursa)

"Osmanlı topraklarının dinler ve medeniyetler tarihi içindeki ehemmiyeti ve bilhassa İstanbul, pek çok Avrupalı fotoğraf̧̧ı için cazibe noktası teşkil etmiştir" (Yılmaz, 2009:31). Albümlerde yer alan çok sayıdaki İstanbul fotoğrafı Sarayın İstanbul'a bakışını da yansıtmaktadır (örnek foto 6). Fotoğrafçıların özellikle İstanbul'un güzelliklerini sunmaya çalışırken belirli yerleri ve yapıları tercih ettikleri, en çok anıtsal yapılar, saraylar, camiler, türbeler ve sebillerin fotoğraflara yansıdığı görülmektedir. Hastaneler, karakollar, çeşmeler, okullar devrin yeni yapıları olarak fotoğraflara konu olmuşlardır. Yıldız Sarayı Fotoğraf Koleksiyonunda bulunan panoramik fotoğraflar da sanatsal, mimari ve diğer pek çok açıdan önemlidir. Fotoğrafçıların Sultanahmet ve Beyazıt Meydanı'na da ilgi gösterdikleri, İstanbul Boğazı'nın Anadolu ve Rumeli yakalarının panoramik fotoğraflarının karşı taraftaki tepelerden çekilerek hazırlandığı anlaşılmaktadır. Haliç'in panoramik fotoğrafının Galata Kulesi'nin tepesinden çekilebildiği. Suriçi eski İstanbul'un panoramik fotoğraflarının çekiminin ise Beyazıt Yangın Kulesi’nden yapıldığg anlaşılmaktadır.

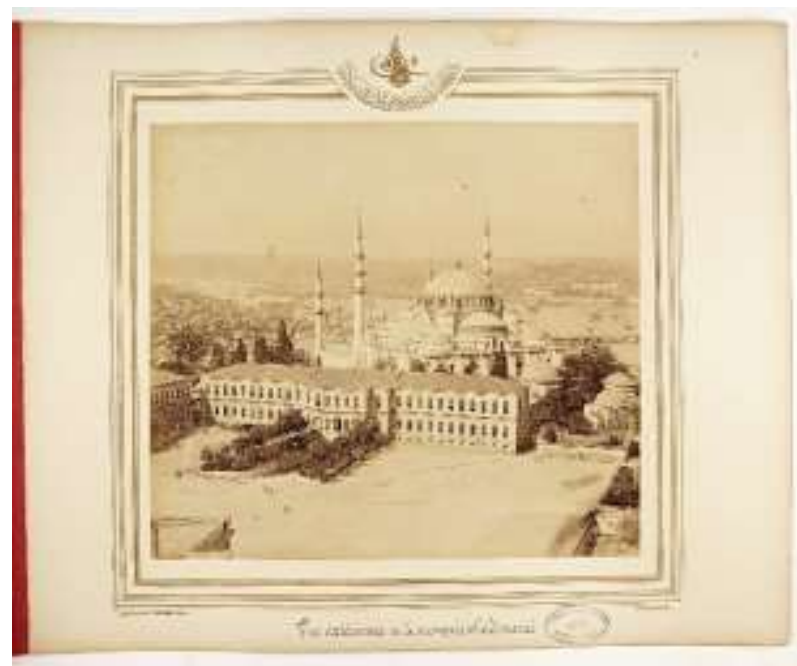

90839/9

Fotoğrafçı: Abdullah Fréres.

Fotoğraf adı: Süleymaniye Camii ve seraskerlik.

Fotoğrafın konusu: Süleymaniye Camii, İstanbul, Mimari, Dini yapılar, Camiler.

Fiziksel özellikler : Siyah-beyaz, $38 \times 31 \mathrm{~cm}$.

Paspartu: Beyaz karton, yaldız cetvelli, $50 \mathrm{x} 44 \mathrm{~cm}$.

Yayın Bilgileri: İstanbul, Abdullah Fréres, 1894.

Foto 6. 90839/9, Süleymaniye Camii ve seraskerlik. 
"Sultan II. Abdülhamid'in dönemi bir anlamda monarşinin son yüzy1lı olduğu düşünüldügünde, fotoğraf arşivinde yer alan dünya liderleri fotoğrafları adeta kapanan bir dönemin liderlerinin geçit töreni niteliğindedir. Albümde Sicilya, Hannover krallıkları gibi tarihe gömülen hanedanlıklarına karşılık Malezya'da bugün hala varlığını koruyan Johar Sultanlığı'nın hükümdarları Ebubekir Han'a kadar devrin en önemli simaları yer almaktadır" (Yılmaz, 2011:11). Albümlerde kraliyet ailelerinin yanı sıra bazı politikacılara yer verilmesi de dikkat çekmektedir (örnek foto 7). Bu politikacılar muhtemelen dönemin güçlü siyasi isimleri olmaları sebebiyle albümlerde yer almaktadır.

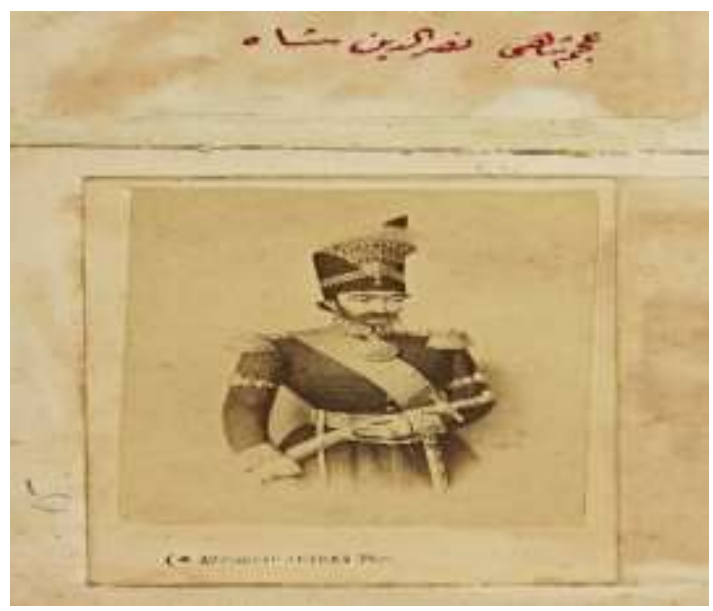

\section{$90628 / 51$}

Fotoğrafçı: Abdullah Fréres.

Fotoğraf adı: Sadrazam Mehmed Fuad Paşa.

Fotoğrafin konusu: Bakanlar, Devlet adamları, Bürokratlar, Askerler, Türkiye, Siyasetçiler.

Fiziksel özellikler: Siyah-beyaz, 11x6 cm.

Paspartu ölçüsü: 31x12 cm.

Yayın bilgileri: İstanbul, Abdullah Biraderler,

1909.

Foto 7. 90628/51, Sadrazam Mehmed Fuad Paşa

Sultan II. Abdülhamid'in aile fotoğraflarının albümlerde yer alması, Osmanlı Devleti'nin gelecekteki yapısını oluşturacak olan şehzade ve sultanlarını (örnek foto 8) bu fotoğraflarda görülebilmesi de önemlidir. "Yıldız Albümlerinde II Abdülhamid'e kadar Osmanlı padişahlarının çoğu Sultan II. Selim zamanında Ressam Kapıdağlı Kontantin tarafindan çizilmiş portrelerinden çekilmiş fotoğrafları bulunmaktadır. Ancak Sultan'ın bizzat kendisine ait fotoğraf bulunmamaktadır. Abdullah Kardeşler, Sultan II. Abdülhamid' in fotoğrafinı çekmişlerse de Sultan 'in emriyle 26 Aralık 1880 'de çıkarılan bir iradeye dayanılarak ilgili fotoğrafların nüshaları ve bu fotoğrafin cam negatifleri imha edilmiştir" (Y1lmaz, 2009:12).

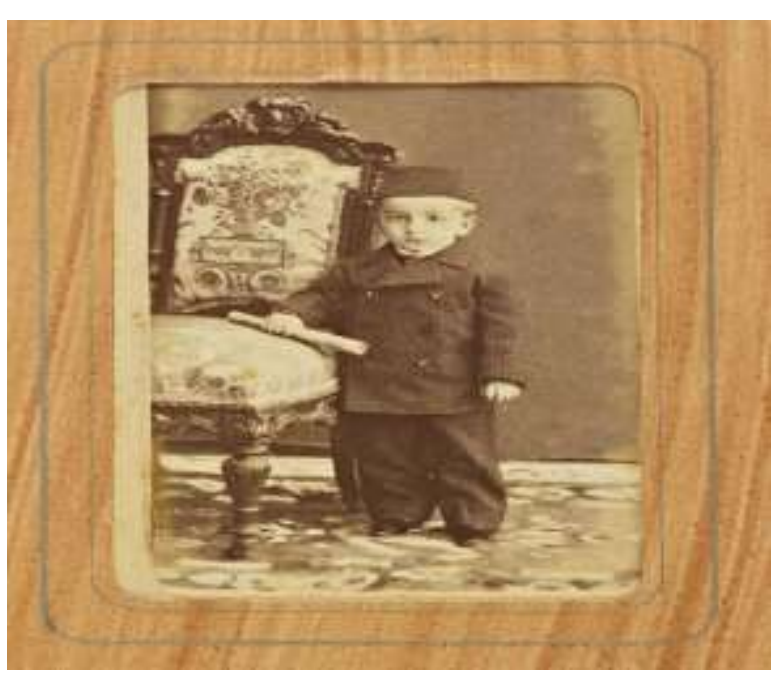

\section{$90897 / 15$}

Fotoğrafçı: Kargopoulo, Basile.

Fotoğraf adı: Şehzade

Fotoğrafin konusu: Şehzadeler, dekorasyon ve süsleme,1299-1922 görsel çalışmalar

Fiziksel özellikler: siyah-beyaz.

Paspartu: Sarı renkli karton. 33x22 cm. 
Foto 8. 90897/15, Şehzade

II. Abdülhamid albüm koleksiyonu fotoğraf sanatı açısından da önemli bir kaynak eserdir. Albüm, fotoğraf sanatçıları açısından ele alındığında dönemin en büyük ustalarının karelerini içermektedir. Fotoğraf sanatçılarının çoğu İstanbul merkezli Ermeni, Yunan veya Fransız ticari fotoğrafçılarıydı. Saray fotoğrafçıları arasından en çok bilinen, en başarılı olanlardan biri (Abdullah biraderler olarak tanınan) Vigen, Hovsep ve Gevork adlı üç Ermeni kardeş olan Abdullah Freres'in firmasıydı (Walley, 1991:119). Osmanlı fotoğrafçılarının işlerinin bir kısmı, Osmanlı seçkinleri ve yabancı saygınlar için portre fotoğrafçılığıydı. Sultan'ın fotoğrafçıları olarak, Basile Karopoulo ve daha sonra Abdullah Fréres, kraliyet ailesini ve Sultan'ın kabinesini fotoğraflama ayrıcalığına sahipti (Greene, 2010:6). "Fotoğrafin yaygınlaşması sonrası, Müslüman teb'anın da bu sanatla iştigali artmış ve fotoğrafçıların en iyilerine "ressam-1 şahriyari, fotoğrafi-i hazret-i şehriyari" gibi ünvanların verilmesi, şehzadelerin fotoğrafçılık dersi alması gibi noktalar Saray'ın konuya verdiği önemi göstermektedir. Saray albümlerinde, "fotoğrafçı veya fotoğrafhane olarak ilk tespitlere göre varılan adet 263 olup bu sayımda aynı şahsa ait olduğu bilinen farklı unvanlı imzalar tek sayılmıştır" (Y1lmaz, 2009:31-46).

Fotoğrafın kullanım alanının ne kadar geniş olduğunu gösteren bu albümler özgün ciltleri, zarif mizanpajları ve süslemeleri, farklı dillerde hazırlanmış edisyonları, foto alt bilgileri ile de dönemin sanat, estetik anlayışını (örnek foto 9) ve arşivcilik faaliyetini de göstermektedir. Osmanlı fotoğraf tarihi açısından çok önemli olan bu fotoğraflar yüksek belge değeri ile tarihe 1şık tutmaktadır (Koca1ş1k \& Uslu,2015:517). Albüm kapaklarında genelde bordo ve yeşil kadife tercih edilmiştir. Albümler arasında 78x55 gibi büyük ebatlarda ve ağır albümler yanı sıra 41x32 gibi küçük ebatlarda albümler de bulunmaktadır. Çeşitli kompozisyonlar içeren albümlerin kapak süslemelerinde ortak özellik Osmanlı arması kullanılmasıdır (Atasoy, 2007:.8-9).

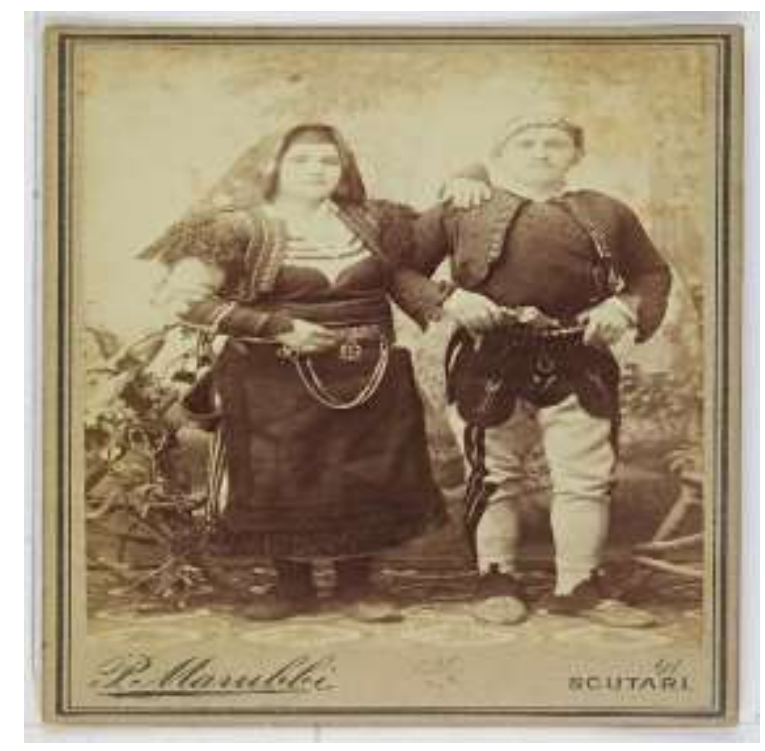

\section{AA91299/39}

Fotoğrafç1: Marubbi, Pietro.

Fotoğraf adı: İşkodra ve Tiran halkından görünümler.

Fotoğrafin konusu: İşkodra (Arnavutluk), Tiran (Arnavutluk), Toplumsal yaşam, Giyim ve giysi, Kültürel özellikler.

Fiziksel özellikler: Siyah-beyaz, $14 \times 10 \mathrm{~cm}$.

Paspartu: Beyaz karton, 16x11 cm.

Yayın Bilgileri: İşkodra, Pietro Marubbi Fotoğrafhanesi, [tarih yok]

Foto 9. AA91299/39, İşkodra ve Tiran halkından görünümler.

Yukarıda bahsi geçen fotoğraf konuları ile ilgili, İstanbul Üniversitesi Nadir Eserler Kütüphanesi'nde bulunan Yıldız Sarayı II. Abdülhamid Albüm Koleksiyonunda yer alan konular ve sayılarının tespit edilebilmesi için bir inceleme ve analiz çalışması yapılmıştır. İnceleme için İstanbul Üniversitesi Entegre Kütüphane Otomasyon Sistemi üzerindeki kayıtlardan fotoğraflar tek tek 
kontrol edilerek verilere ulaşılmıştır. Aşağıdaki tablolarda görüldüğg̈ üzere inceleme sonucunda; konularına göre fotoğraf sayıları yanı sıra fotoğraflarda yer alan şehir ve ülke adlarına göre de fotoğraf sayıları elde edilmiştir.

Tablo 1: İstanbul Üniversitesi Yıldız Sarayı Albümlerindeki Konularına Göre Fotoğraf Sayıları

\begin{tabular}{|l|c|}
\hline \multicolumn{2}{|c|}{$\begin{array}{c}\text { İstanbul Üniversitesi Nadir Eserler Kütüphanesi } \\
\text { Yııtdığgaf Sayayıları } \\
\text { Konularına Göre }\end{array}$} \\
\hline Konu Başlığı & $\begin{array}{c}\text { Fotoğraf } \\
\text { Sayısı }\end{array}$ \\
\hline Siyaset Bilimi & 1160 \\
\hline Hukuk & 2424 \\
\hline Askeriye & 2435 \\
\hline Eğitim & 8330 \\
\hline Tıp & 1221 \\
\hline Sosyoloji & 794 \\
\hline Zanaat ve El İşleri & 1160 \\
\hline Sanat & 1302 \\
\hline Sanat Tarihi & 1755 \\
\hline Giyim & 1072 \\
\hline Mimari Bilimler ve İnşaat & 5148 \\
\hline Dini Kurum ve Yapılar & 3541 \\
\hline Coğrafya & 982 \\
\hline Tarım ve Hayvancılık & 303 \\
\hline Ulaşım ve Taşımacılık & 2594 \\
\hline
\end{tabular}

Bu tabloda, İstanbul Üniversitesi Nadir Eserler Kütüphanesi'nde bulunan Y1ldız Sarayı Albümlerindeki fotoğraf sayıları görülmektedir. Tabloya göre konusal sayı dağılımı şu şekildedir; tarih 1160, siyaset bilimi 2424, hukuk 2435, askeriye 8330, eğitim1221, tıp 794, sosyoloji 1160, zanaat ve el işleri 1302, sanat 1755 , sanat tarihi 1072 , giyim 5148, mimari bilimler ve inşaat 3541 , dini kurumlar ve yapılar 982, coğrafya 303 , tarım ve hayvancılık 2594, ulaşım ve taşımacılık 1828.

Fotoğraf sayısının, askeri erkan, askeri kışla, lojman, kale, gibi yapılar, askeri eğitim kurumlarına ait görselleri içeren, askeriye konu başlı̆̆ında en fazla olduğu, ikinci olarak resmi, sivil, yöresel ve azınlıklara ait giyim kuşam görsellerini içeren giyim konusu, üçüncü sırada cami, kilise, çeşme, köprü vs. yapıları içeren mimarlık alanı ve dördüncü olarak da tarım ve hayvancılık alanında fotoğraf sayısının daha çok olduğu dikkati çekmektedir.

Fotoğraflarda yer alan ve yukarıda verilen genel konu başlıklarının alt başlıkları ve fotoğraf sayıları şu şekildedir: Abideler 7, Adetler/törenler 134, Adli vakalar 54, Adliyeler 66, Ağaç işçiliği 12, A ğaçlar 84, Ahırlar 663, Ahşap malzemeler 8, Akarsular 7, Aktörler, Alman 12, Anıtlar 24, Antik kentler 49, Araplar 131, Arenalar 21, Arkeoloji 192, Arkeoloji müzeleri ve koleksiyonlar1 27, Arkeolojik eserler 17, Armalar26, Askeri araç gereçler 58, Askeri binalar/yapılar 135, Askeri eğitim 181, Askeri giyim ve giysi 951, Askeri madalyalar 1036, Askeri mimari 140, Askeri okul öğrencileri 43, Askeri okullar 118, Askeri sancaklar 52, Askeri silahlar 1170, Askeri tarih 166, Askeri törenler 25, Askeri üniformalar 676, Askerler 2907, Askerler bakım ve tedavi 50, Aşiretler 102, At yetiştiriciliği 8, Atçılık 606, Ateşli silahlar 532, Atlar 699, Atlı arabalar 60, Av köpekleri 42, Aydınlatma 154, Azınlıklar 15, Bahçeler 213, Bakanlar 70, Bavyera Hanedanı (Almanya) 70, Belediyeler 40, Binalar, yapılar vb. 752, I. Dünya Savaş1 1914-1918 4, Budizm 24, Büstler 99, Caddeler 66, Camiler 576, Cezaevleri 22, Çarşılar 12, Çeşmeler 59, Çiftlik yapıları 36, Çiftlikler 55, Çingeneler 9, Çocuk bakım hizmetleri 13, Çocuk bakım ve tedavi 17, Çocuk yuvaları 16, Dağlar 74, Darülaceze 136, Dekorasyon ve süsleme 464, Dekoratif sanatlar 100, Demiryollar1 565, Demiryolu istasyonları 33, Demiryolu taşımacılığı 20, Deniz kuvvetleri 192, Denizaltılar 19, Denizcilik 31, Deprem etkileri 25, Devlet adamları 502, Devlet adamları giyim ve giysi/üniforma 441, Devlet başkanları 44, Devlet başkanları ziyaret 48, Devlet memurları 572, Din adamları 31, Dini yapılar 46, Doktorlar 15, Dokuma Sanayi 28, Donanma 164, Duvar resmi ve dekorasyonu 21, Duvar süslemeleri 10, Eğitim 200, Ermeniler 58, Esirler 19, Eşkiyalar, suçlular 2182, Evlilik adetleri ve törenleri 55, Fabrikalar 207, Firigler 8, Freskler 7, Fuarlar 80, Galeriler 12, Gaziler 49, Gemi 
mürettebatları 8, Gemi yapım sanayi 15, Gemiler 404, Giyim endüstrisi 49, Giyim ve giysi 1955, Göç ve göçmenlik 6, Göçmenler 19, Göller 13, Görüntüleme sistemi (Tıp) 10, Güvenlik 152, Güzel sanatlar 65, Halıcilık 6, Hamamlar 16, Hamidiye Etfal hastanesi 12, Harabeler 81, Haritalar 13, Hastalar 74, Hastane mimarisi 85, Hastaneler 326, Hayvanat bahçeleri 50, Hayvancilık 17, Hayvanlar 133, Hediyelik ve turistik eşya mağazaları 6, Heykeller 78, Hicaz Demiryolları 466, Hohenzollern Hanedanı 22, Hükümlüler 83, İçme Suyu 15, İlkyardım 20, İnsanlar 242, İnşaat Mimari 34, İtfaiye 35, İtfaiye teşkilatı 50, İtfaiyeciler 23, Kabileler 112, Kadın hastalıkları (cerrahi) 8, Kağıt yapımı 36, Kaleler 77, Kamu binaları 22, Kamu kurumları 37, Kaplıcalar 65, Karakollar 193, Karayolları 17, Kasırlar 18, Kataloglar 764, Kayık yarışları 17, Kent, şehir, kasaba 116, Kırım Savaş1, 1853-1856 5, Kışlalar 25, Kiliseler 39, Konaklar 64, Konsolosluklar 31, Köprüler 115, Köşkler 38, Köşkler ve kasırlar 175, Köyler 188, Köylüler 39, Krallar 23, Kruvazörler 21, Kuleler 21, Kuşlar 132, Kutsal mekanlar (İslami) 181, Kümes hayvanları 93, Kürtler 9, Kütüphaneler 49, Limanlar 174, Lokomotifler 11, Mabetler 58, Mağaralar 18, Mahkemeler 9, Maliye 22, Manastırlar 27, Manzara 59, Mareşaller 14, Memlükler 3, Meydanlar 11, Mezarlar 35, Milletvekilleri 109, Mimari 657, Misafirhaneler 7, Mitoloji 27, Mobilyalar 85, Mozaik 6, Muhalifler 40, Müzeler 226, Nehirler 33, Okullar 243, XIV. Louis Stili Servis Takımı Kataloğu 61, Ordu (Türk/Osmanlı-Diğer ülkeler) 2510, Ormanlar 12, Oryantalistler 4, Oteller 14, Ovalar 9, Öğrenciler 115, Öğretim üyeleri 266, Padişahlar 34, Parklar 26, Petrol kuyuları 19, Piramitler 14, Polisler 76, Porselen 8, Prensesler 31, Prensler 62, Resimler 130, Resmi binalar 14, Resmi ziyaretler 39, Ressamlar 10, Rihtımlar 3, Rumenler 42, Rumlar 9, Saat kulesi 13, Sağlik hizmetleri 31, Sağlık kurumları 42, Sanat 356, Saraylar 259, Savaş gereçleri 31, Savunma endüstrisi 26, Seremoniler 20, Sergiler 160, Silah Sanayi 36 , Siyasetçiler 22, Sosyal hayat ve gelenekler 561, Sosyal hizmetler 6, Sosyal yardım kurumları 36, Su kaynakları 15, Su yönetimi 76, Suçlular, eşkiyalar 2182, Sultanlar 50, Sütunlar 26, Şahıs fotoğrafları 60, Şehzadeler 28, Şelaleler 19, Tabiat 49, Tablolar 83, Tarihi eserler 19, Tarihi yapılar 7, Tekstil ürünleri 14, Terör hareketleri 49, Ticaret 78, Tiyatrocular 46, Toplar 33, Tramvaylar 10, Transvaal Savaş1 84 Tüneller 8, Türbeler 71, Türk Kızılayı 1877- 15, Türk-Rus Savaş1, 1877-1878 290, Türk-Yunan Savaşı, 1897 81, Ulaşım 94, Valiler 10, Yabancı sermaye yatırımları 29, Yardım kuruluşları 13, Yazarlar 7, Yerliler 25, Yıldız Çini ve Porselen 101, Yöneticiler 13, Yörükler 19, Ziyaretler 130.

Aşağıdaki tablo 2-5'de ise, İstanbul Üniversitesi Nadir Eserler Kütüphanesi'nde bulunan Yıldız Sarayı Albümlerinde konu edilen şehir ve ülkelerin hangileri olduğu ve fotoğraf sayılarının inceleme sonuçları yer almaktadır. İnceleme sırasında yer isimleri fotoğrafta geçtiği haliyle aynen ve günümüz Türkçesi ile yazılmıştır. İnceleme sonuçlarına göre ülke ve şehir adları ve fotoğraf sayıları alfabetik olarak şu şekildedir; 
Tablo 2: İstanbul Üniversitesi Yıldız Sarayı Albümlerindeki Şehirler ve Ülkelere Göre Fotoğraf Sayıları (A-B Grubu)

\begin{tabular}{|c|c|c|c|}
\hline \multicolumn{2}{|c|}{$\begin{array}{l}\text { İstanbul Üniversitesi Nadir Eserler Kütüphanesi } \\
\text { Yıldız Albümlerindeki Fotoğraf Sayıları } \\
\text { (Şehirler-Ülkeler A Grubu) }\end{array}$} & \multicolumn{2}{|c|}{$\begin{array}{c}\text { İstanbul Üniversitesi Nadir Eserler Kütüphanesi } \\
\text { Yıldız Albümlerindeki Fotoğraf Sayıları } \\
\text { (Şehirler-Ülkeler B Grubu) }\end{array}$} \\
\hline Şehir/Ülke & $\begin{array}{c}\text { Fotoğraf } \\
\text { Say1s1 }\end{array}$ & Şehir/Ülke & Fotoğraf Sayısı \\
\hline Adana & 79 & Baalbek/Lübnan & 45 \\
\hline Adapazar1 & 12 & Baden/Almanya & 27 \\
\hline Aden/Yemen & 3 & Bağdat/Irak & 138 \\
\hline Adiyaman & 1 & Balıkesir & 53 \\
\hline Afrika & 116 & Balkanlar/Balkan Yarımadas1 & 82 \\
\hline Afyonkarahisar/Afyon & 38 & Bandırma/Balıkesir & 13 \\
\hline Akabe/Ürdün & 127 & Bengalore/Hindistan & 2 \\
\hline Akçadağ/Malatya & 40 & Bergama/İzmir & 5 \\
\hline Akka/Filistin & 42 & Berlin/Almanya & 58 \\
\hline Alasonya/Yunanistan & 15 & Beşiktaş/İstanbul & 53 \\
\hline Almanya & 1591 & Beykoz/İstanbul & 49 \\
\hline Amasya & 6 & Beyrut/Lübnan & 181 \\
\hline Amerika Birleşik Devletleri & 711 & Beytüllahim/Filistin & 16 \\
\hline Amman/Ürdün & 11 & Bilecik & 55 \\
\hline Ankara & 105 & Boğaziçi/İstanbul & 30 \\
\hline Antakya & 69 & Bombay/Hindistan & 18 \\
\hline Antep & 69 & Borneo adas1/Endonezya & 5 \\
\hline Arjantin & 4 & Boston/ABD & 13 \\
\hline Arnavutluk & 10 & Brüksel/Belçika & 53 \\
\hline Atina/Yunanistan & 117 & Buhara/Özbekistan & 14 \\
\hline Avusturya & 243 & Bulgaristan & 68 \\
\hline Ayazağ 1 (Şişli)/İstanbul & 26 & Bursa & 244 \\
\hline Aydin & 123 & Büyükada/İstanbul & 23 \\
\hline
\end{tabular}


Tablo 3: İstanbul Üniversitesi Yıldız Sarayı Albümlerindeki Şehirler ve Ülkelere Göre Fotoğraf Sayıları (C-J Grubu)

\begin{tabular}{|l|c|l|c|}
$\begin{array}{c}\text { İstanbul Üniversitesi Nadir Eserler Kütüphanesi } \\
\text { Y1ldız Albümlerindeki Fotoğraf Sayıları } \\
\text { SSehirler-Ülkeler C-Ç-D-E-F-G Grubu) }\end{array}$ & $\begin{array}{c}\text { İstanbul Üniversitesi Nadir Eserler Kütüphanesi } \\
\text { Y1ldı Albümlerindeki Fotoğraf Saylları } \\
\text { (Şehirler-Ülkeler H-I-İ-J Grubu) }\end{array}$ \\
\hline Şehir/Ülke & Fotoğraf Sayıs1 & Şehir/Ülke & Fotoğraf Sayıs1 \\
\hline Cava Adası/Endonezya & 23 & Halep/Suriye & 29 \\
\hline Çanakkale & 28 & Halilürrahman/Filistin & 13 \\
\hline Çek Cumhuriyeti & 65 & Halkal/İstanbul & 12 \\
\hline Çerkezköy/Tekirdağ & 5 & Hasankeyf/Batman & 4 \\
\hline Çin & 60 & Hatay & 52 \\
\hline Çorlu/Tekirdağ & 11 & Haydarpaşa/İstanbul & 20 \\
\hline Dedeağaç/Yunanistan & 29 & Hayfa/Filistin & 8 \\
\hline Delhi/Hindistan & 13 & Hereke/İzmit-Kocaeli & 8 \\
\hline Denizli & 35 & Hindistan & 210 \\
\hline Diyarbakır & 29 & Humus/Suriye & 23 \\
\hline Edirne & 120 & Irak & 157 \\
\hline Endonezya & 107 & İdlib & 13 \\
\hline Erzincan & 22 & İngiltere & 358 \\
\hline Erzurum & 47 & İran & 73 \\
\hline Eskişehir & 256 & İskenderun/Hatay & 22 \\
\hline Filistin & 478 & İspanya & 86 \\
\hline Fransa & 502 & İstanbul & 4013 \\
\hline Gazze/Filistin & 11 & İsviçre & 87 \\
\hline Gelibolu/Çanakkale & 14 & İşkodra & 5 \\
\hline Gümülcine/Yunanistan & 10 & İtalya & 673 \\
\hline & & İzmir & 93 \\
\hline & & İzmit & 12 \\
\hline & & Japonya & 185 \\
\hline
\end{tabular}


Tablo 4: İstanbul Üniversitesi Yıldız Sarayı Albümlerindeki Şehirler ve Ülkelere Göre Fotoğraf Sayıları (K- Ö Grubu)

\begin{tabular}{|l|c|l|c|}
\hline $\begin{array}{c}\text { İstanbul Üniversitesi Nadir Eserler Kütüphanesi } \\
\text { Yıldz Albümlerindeki Fotoğraf Sayları } \\
\text { (Şehirler-Ülkeler K-L Grubu) }\end{array}$ & $\begin{array}{c}\text { İstanbul Üniversitesi Nadir Eserler Kütüphanesi } \\
\text { Y1ldız Albümlerindeki Fotoğraf Sayıları } \\
\text { (Şehirler-Ülkeler M-N-Ö Grubu) }\end{array}$ \\
\hline Şehir/Ülke & Fotoğraf Sayısı & Şehir/Ülke & Fotoğraf Sayıs1 \\
\hline Kafkasya & 20 & Madrid/İspanya & 26 \\
\hline Kağıthane/İstanbul & 26 & Makedonya & 143 \\
\hline Kahire/Mısır & 78 & Malatya & 4 \\
\hline Kaliforniya/ABD & 6 & Malkara/Tekirdăg & 19 \\
\hline Kanada & 28 & Manastır/Makedonya & 145 \\
\hline Karadağ & 26 & Manisa & 21 \\
\hline Karaköy/İstanbul & 8 & Maraş & 8 \\
\hline Kastamonu & 41 & Mardin & 8 \\
\hline Kayseri & 21 & Maslak/İstanbul & 55 \\
\hline Keşmir/Hindistan & 3 & Medine/Arabistan & 23 \\
\hline Kirklareli & 86 & Mehadia/Romanya & 104 \\
\hline Kilis & 22 & Mekke/Arabistan & 41 \\
\hline Konya & 132 & Meksika & 12 \\
\hline Kosova & 7 & Mersin & 202 \\
\hline Kudüs/Filistin & 251 & Misır & 16 \\
\hline Kütahya & 20 & Midilli Adasi/Yunanistan & 6 \\
\hline Lazkiye/Suriye & 30 & Mudanya/Bursa & 41 \\
\hline Libya & 36 & Musul/Irak & 160 \\
\hline Londra & 66 & Nablus/Filistin & 38 \\
\hline Lübnan & 328 & New York/ABD & \\
\hline Lüleburgaz & 9 & Özbekistan & \\
\hline
\end{tabular}


Tablo 5: İstanbul Üniversitesi Yıldız Sarayı Albümlerindeki Şehirler ve Ülkelere Göre Fotoğraf Sayıları (P-Y Grubu)

\begin{tabular}{|c|c|c|c|}
\hline \multicolumn{2}{|c|}{$\begin{array}{l}\text { İstanbul Üniversitesi Nadir Eserler Kütüphanesi } \\
\text { Yıldız Albümlerindeki Fotoğraf Sayıları } \\
\text { (Şehirler-Ülkeler P-R-S Grubu) }\end{array}$} & \multicolumn{2}{|c|}{$\begin{array}{l}\text { İstanbul Üniversitesi Nadir Eserler Kütüphanesi } \\
\text { Yıldız Albümlerindeki Fotoğraf Sayıları } \\
\text { (Şehirler-Ülkeler Ş-T-U-Ü-V-X-Y Grubu) }\end{array}$} \\
\hline Şehir/Ülke & Fotoğraf Sayısı & Şehir/Ülke & Fotoğraf Sayısı \\
\hline Paris/Fransa & 204 & Şam/Suriye & 243 \\
\hline Polonya & 41 & Şanlıurfa & 12 \\
\hline Pompei/Italya & 60 & Tahran/İran & 12 \\
\hline Port Said/Misir & 17 & Taşkent/Özbekistan & 3 \\
\hline Prag/Çek Cumhuriyeti & 65 & Tayland & 7 \\
\hline Remle (Ramle)/Filistin & 8 & Tebük/Arabistan & 16 \\
\hline Rodos Adas1/Yunanistan & 108 & Tekirdağ & 38 \\
\hline Roma & 80 & Tirnovacık/Kırklareli & 27 \\
\hline Romanya & 134 & Tokat & 16 \\
\hline Rumeli & 18 & Trablusşam/Lübnan & 57 \\
\hline Rumkale & 20 & Tunus & 99 \\
\hline Rusya & 259 & Turgutlu/Manisa & 6 \\
\hline Sakarya & 30 & Umber/Hindistan & 5 \\
\hline Samarra/Irak & 4 & Ürdün & 44 \\
\hline Samsun & 24 & Van & 5 \\
\hline San'a/Yemen & 32 & Vatikan & 13 \\
\hline Selanik/Yunanistan & 298 & Xanthi - İskeçe/Yunanistan & 8 \\
\hline Semerkand/Özbekistan & 10 & Yanya/Yunanistan & 43 \\
\hline Serez/Yunanistan & 228 & Yemen & 110 \\
\hline Surbistan & 95 & Yozgat & 42 \\
\hline St. Petersbourg/Rusya & 20 & Yunanistan & 539 \\
\hline Sudan & 16 & & \\
\hline Suriye & 621 & & \\
\hline Suudi Arabistan & 205 & & \\
\hline
\end{tabular}

\section{Sultan II. Abdülhamid Albümlerinin Araştırmacı Profilleri ve Çalışma Alanları}

Yıldız Sarayı Fotoğraf Koleksiyonu sadece bir kültür hazinesi olmayıp birçok farklı alanı ilgilendiren görselleri bünyesinde barındırdığından farklı bilim ve sanat dalları açısından da önemli bir veri kaynağı olarak karşımıza çıkmaktadır. Aşağıda bu koleksiyonun diğer bilim ve sanat dalları açısından ne tür ögeler içerdiği hakkında kısa bilgi verilmiştir:

$\checkmark$ Tarih (Önemli tarihi şahsiyetlerin, yerlerin, olayların ve eserlerin görselleri)

$\checkmark$ Sanat (Resim ve heykel başta olmak üzere birçok sanat eserinin görselleri)

$\checkmark$ Musiki (Müzik aletleri, bandolar, şarkıcılar, gösteriler vb. görseller)

$\checkmark$ Giyim (Resmi, sivil, yöresel ve azınlıklara ait giyim kuşam resimleri)

$\checkmark$ Sanat tarihi (Sanat eserlerinden başka sanatçılara, sanat atölyelerine ait resimler)

$\checkmark$ Zanaat ve el işleri (Farklı zanaat dallarında eser ve zanaatkârlarına ait görseller)

$\checkmark$ Tarım ve hayvancılık (Farklı yörelerde kullanılan tarım aletleri, ürün, hayvan ve çiftlik vb. görseller)

$\checkmark$ Mimari bilimler ve inşaat (Cami, çeşme, hamam, şadırvan, köprü, sütun, tapınak, harabe, kilise, anıt, heykel, şato, kilise, patrikhane, piramit vb. tarihi eserlere ait resimler)

$\checkmark$ Tip (Hastane, eczane, ameliyathane vb. yerlere, hasta ve hastane personeline ait görseller) 
$\checkmark$ Askeriye (Askeri erkân, askeri kışla, lojman, kale vb. yapılar, eğitim öğretim kurumlarına ait görseller)

$\checkmark$ Siyaset (Siyaset adamları, bürokratlar, memurlar, azınlıklar vb. birçok görsel)

$\checkmark$ Eğitim (Sivil ve askeri okullar, öğrenciler, hocalar, personel ve eğitim araçlarına ait görseller)

$\checkmark$ Hukuk, ilahiyat, sosyoloji, coğrafya vb. dalları ilgilendiren fotoğraflar

Dolayısıyla, bu alanlarla ilgili farklı disiplinlerden pek çok araştırmacı albümler ile ilgili film, belgesel, tıpkı basım (röprodüksiyon), akademik yayın, sergi vs. amaçlı çeşitli çalışmalar yapmaktadır. Bu çalışmalar kapsamında bazı araştırmacılar albümlerin ciltleri ile bazıları albümlerde kullanılan malzeme türleri ile bazıları albüm içerikleri ile ilgilenmektedir. Albümler hakkında hangi alanlardan, hangi meslek grupları, hangi konularda araştırma yapmaktadır sorusunun yanıtını aramak üzere bu çalışma kapsamında; İstanbul Üniversitesi Nadir Eserler Kütüphanesi’nde bulunan II. Abdülhamid Albümlerini kullanan araştırmacı profilleri analizi yapılmıştır. Analiz yapılırken, İ̈̈ Nadir Eserler Kütüphanesi Kullanıcı Hizmetleri Bölümünde elektronik ve basılı olarak düzenli şekilde tutulan kullanıcı formları ile elektronik belge yönetim sistemi ve e-posta yoluyla gelen kullanıcı talep yazışma arşivleri incelenmiştir. Aşağıdaki tablo 6'da detayları yer alan, 2016-2020 yıllarını kapsayan, bu inceleme sonuçlarına göre; tarih alanındaki araştırmacıların albüm fotoğrafları ile daha çok ilgilendikleri ve bunların çoğunluğunun akademisyen olduğu ancak tarih alanından öğrenci ve çeşitli kamu kurumu görevlileri ile bazı sivil toplum kuruluşlarının (STK) ilgi düzeyinin de diğer alanlara göre yüksek olduğu anlaşılmaktadır. Albümlerle en çok ilgilenen diğer meslek grubunun sanat tarihçileri, mimarlık tarihi ve restorasyon alanından olduğu, gene bu gruptaki araştırmacıların da çoğunluğunun akademisyen oldukları dikkati çekmektedir. Diğer dikkati çeken bir husus ise, çeşitli yönleri ile çeşitli çalışmalara malzeme olan böyle değerli bir fotoğraf koleksiyonuna fotoğrafçılık alanından araştırmacıların ilgi düzeyinin düşük olmasıdır.

Tablo 6: İstanbul Üniversitesi Yıldız Sarayı Albümleri Araştırmacı Profilleri ve Çalışma Alanları (2016-2020)

\begin{tabular}{|c|c|c|c|c|c|c|c|}
\hline \multicolumn{8}{|c|}{$\begin{array}{c}\text { İstanbul Üniversitesi Nadir Eserler Kütüphanesi Yıldız Sarayı Albümleri } \\
\text { Araştırmacı Profilleri ve Çalışma Alanları (2016-2020) }\end{array}$} \\
\hline $\begin{array}{l}\text { Araştırmaci } \\
\text { Profilleri }\end{array}$ & \multirow[t]{2}{*}{ Akademisyen } & \multirow[t]{2}{*}{ Öğrenci } & \multirow{2}{*}{$\begin{array}{c}\text { Kamu } \\
\text { Kurumları } \\
\text { ve STK'lar }\end{array}$} & \multirow{2}{*}{$\begin{array}{l}\text { Yayınevi/ } \\
\text { Yapım } \\
\text { Şirketi }\end{array}$} & \multirow{2}{*}{$\begin{array}{l}\text { Mimar/ } \\
\text { Restoratör }\end{array}$} & \multirow[t]{2}{*}{ Diğer* } & \multirow[t]{2}{*}{ Toplam } \\
\hline Çalışma Alanları & & & & & & & \\
\hline Tarih & 71 & 48 & 43 & 11 & & 18 & 191 \\
\hline İktisat Tarihi & 3 & 2 & & & & & 5 \\
\hline Tip Tarihi & 5 & 1 & 1 & & & 3 & 10 \\
\hline Eğitim Tarihi & & 1 & 1 & & & 5 & 7 \\
\hline $\begin{array}{l}\text { Mimarlık Tarihi ve } \\
\text { Restorasyon }\end{array}$ & 31 & 28 & 4 & & 24 & 4 & 91 \\
\hline $\begin{array}{l}\text { Sanat Tarihi/Türk- } \\
\text { İslam Sanatı }\end{array}$ & 32 & 23 & 10 & 5 & & 9 & 79 \\
\hline $\begin{array}{l}\text { Biyografi } \\
\text { Çalışmaları }\end{array}$ & 1 & 3 & 1 & & & 7 & 12 \\
\hline $\begin{array}{l}\text { İletişim (Televizyon- } \\
\text { Sinema ve Gazetecilik) }\end{array}$ & 3 & 3 & & 1 & & & 7 \\
\hline Fotoğrafçılık & 5 & 1 & & & & 2 & 8 \\
\hline Türk Dili ve Edebiyatı & 7 & 1 & & & & & 8 \\
\hline TOPLAM & 158 & 111 & 60 & 17 & 24 & 48 & 418 \\
\hline
\end{tabular}

*Avukat, doktor, fotoğrafçı, öğretmen, araştırmac1-yazar 


\section{5. İstanbul Üniversitesi Sultan II. Abdülhamid Han Fotoğraf Albümleri Projesi}

“İstanbul Üniversitesi Nadir Eserler Kütüphanesi’nde en eski eserler en yeni teknolojik sistemlerle hizmete sunulmaktadır. Değerli eserlerin korunması, yıpranmasının önlenmesi, kullanımının yaygınlaştırılması, kültürel mirasın gelecek nesillere güvenli bir şekilde aktarılması ve ulusal/uluslararası tanıtımı amacıyla çeşitli dijitalleştirme projeleri yürütülmektedir. Nadir Eserler Kütüphanesi dijitalleştirme çalışmaları kapsamında; eser türlerine ve niteliklere bağlı olarak yüksek donanımlı tarama cihazları kullanılmaktadır. Ayrıca, hassas ve kırılgan yapıdaki özel yazma eserlerin tarayıcılarla dijitalleştirilmesi uygun olmadığından yüksek donanımlı (sensör çözünürlüğü ve sensör boyutları yüksek, orijinal görüntü formatı RAW, lenslerinin büyütme oranı en az 1:1 olan orta format) nadir eserler için uygun nitelikte fotoğraf makinesi kullanılmaktadır.

Dijitalleştirme projeleri ve çalışmalar sonucu; Nadir Eserler Kütüphanesi koleksiyonunda bulunan yazma, matbu, dergi, gazete, hat, levha, müzik notaları ve albüm türündeki eserlerden 21.310 adedi dijital ortama aktarılmış ve yaklaşık 3 milyon kare görüntü oluşturularak internetten (http://katalog.istanbul.edu.tr/client/tr_TR/default_tr/) erişilebilir hale getirilmiştir” (Bezirci, 2020:116-117).

Bu kapsamda gerçekleştirilen çalışmalardan biri de Sultan II. Abdülhamid Han Fotoğraf Albümleri Projesi'dir. Nadir Eserler Kütüphanesi'nde muhafaza edilen, Sultan II. Abdülhamid Han'ın Yıldız Fotoğraf Koleksiyonu iklimlendirme, güvenlik ve tüm saklama koşulları açısından en üst düzeyde yeterlilik sağlanarak muhafaza edilmektedir. Ancak, koleksiyonun gelecek nesiller için sağlıklı koşullarda daha uzun yıllar muhafaza edilebilmesi ve eserlerin araştırmacı incelemeleri sırasında yıpranmasının önlenmesi de gerekmektedir. Bu yüzden, teknolojinin gelişimi ile paralel olarak, Yıldız Fotoğraf Koleksiyonunun eser kıymeti gereği kondisyon koşullarının muhafazasını sağlayarak, araştırmacıların kullanımına sunmak üzere dijital kopyalarının oluşturulması ihtiyacı doğmuştur. Araştırmacıların fotoğraflara hızlı ve güvenli bir şekilde erişebilmelerinin sağlanması hedefiyle II. Abdülhamid Han Yıldız Albümleri Projesi, Cumhurbaşkanlığı himayesinde, İstanbul Üniversitesi ve TBMM Genel Sekreterliği (Milli Saraylar) işbirliği ile gerçekleştirilmiştir'.

Bu projenin amacı, büyük bir kısmı II. Abdülhamid'in talimatıyla 19. yüzyıl sonu ile 20. yüzyılın başında çekilmiş, değerli bir kültür hazinesi olan Yıldız Fotoğraf Koleksiyonu'nun son teknoloji ile dijitalleştirilerek, kullanıcıların hem fotoğraflara ait meta verilerini (Concept-Based Information Retrieval) hem de fotoğraf içeriklerini birlikte sorgulayarak (Content-Based Information Retrieval) çoklu ortam verisine hızlı ve güvenli bir şekilde erişebilecekleri bulut-tabanlı bir sorgulama ve erişim sistemini geliştirmektir.

Yıldız Fotoğraf Koleksiyonu yalnızca Türk/Osmanlı tarihini görsel olarak belgeleyen bir kaynak değil birçok farklı coğrafya, devlet, ırk ve kültüre ait ögeleri içinde barındıran dünya kültür mirasının bir parçasıdır. Son yıllarda dünyada kültürel mirasın dijital ortama taşınmasına (Digital Heritage) ait birçok Ar-GE projesi ve çalışma yapılmış ve yapılagelmektedir. Sanat eserlerinin

\footnotetext{
1 İstanbul Üniversitesi Yönetim Kurulu'nun, 24 Haziran 1982 tarihli ve 16 no.lu toplantısının 10. Maddesinde yer alan karar uyarınca; İstanbul Üniversitesi Nadir Eserler Kütüphanesi’nde bulunan Abdülhamid dönemi albüm fotoğrafları ilk defa IRCICA tarafindan, analog fotoğraf makineleri ile çekim yapılarak roll film denilen filmlere kaydedilmiştir. Ancak gelişen teknoloji ile beraber yapılan bu çekim kalitesi çalışmalar için yetersiz kalmıştır. Cumhurbaşkanlığı himayesi, İstanbul Üniversitesi ve TBMM Genel Sekreterliği (Milli Saraylar) işbirliği ile yapılan 'Sultan II. Abdülhamid Han Fotoğraf Albümleri Projesi' ile fotoğraflar daha detaylı ve yüksek çözünürlüklü yeni teknolojik cihazlarla yeniden çekilmiştir. Proje başlangıcında, IRCICA ile işbirliği görüşmeleri yapılmış ve IRCICA ekibi tarafından yapılan fotoğraf katalog künyeleri İstanbul Üniversitesi ile paylaşılmıştır. Proje kapsamında, fotoğraflara ait katalog künye çalışmaları daha detaylı olarak yeniden hazırlanmıştır (Bezirci,2020:161).
} 
dijitalleştirilmiş versiyonlarının asıllarına zarar vermeden kullanıcılara web/bulut üzerinden ulaştırılması bu tür çalışmaların nedenlerinden bir tanesidir.

Günümüzde bulut üzerinden verilen hizmetler hızla artmaktadır. Donanım/yazılım satın alma ve bakım maliyetlerinden kurtarması yanında verilen hizmetlerin çeşitliliğinin artması, her yerden hemen erişilebilir olması bulut bilişimi teknolojinin önemli unsurlarından biri haline getirmiştir. Bulut üzerinden verilmesi zorunlu olan böyle bir hizmet, Bulut Bilişim açısından (i) Bulutta veri saklama, (ii) Bulut üzerinden veri madenciliği web servisleri, (iii) Bulut üzerinden resim işleme web servisleri, (iv) Bulut üstünde çoklu-ortam verisinin içerik tabanlı sorgulama web servisleri gibi konularda araştırma, tasarımı, modelleme, geliştirme, test vb. konuları içermektedir. $\mathrm{Bu}$ Proje kapsamında da dijitalleştirilen fotoğraf koleksiyonu üzerinde resim işleme (image processing) ve veri madenciliği (data processing) yöntemleri, araçları ve kütüphaneleri kullanılarak görsel içerik analizi, resim etiketleme (tagging), resim tanımlama (description), içerik-tabanlı sorgulama çalışmaları yapılmıştır.

Yapılan araştırma ve geliştirme faaliyetleri sonucu Yıldız Fotoğraf Koleksiyonuna içerik tabanlı sorgulama ve erişimi sağlayan bir sistem geliştirilirken kabaca aşağıdaki adımlar izlenmiştir:

$\checkmark$ Dijitalleştirme, dönüştürme ve saklama

$\checkmark$ Tanıma ve etiketleme

$\checkmark$ Sorgulama ve erişim

Dijitalleştirme, dönüştürme ve saklama: Bu adım resimlerin kaliteli ve yüksek çözünürlüklü profesyonel fotoğraf makinesiyle taranması ya da fotoğraflanmasını, değişen çözünürlük seviyelerinde bulut-depolama birimlerinde saklanmasını ve çözünürlük seviyesine bağlı olarak veri güvenliğinin sağlanmasını içermektedir. Bu aşamada fotoğrafların belli bir görüntü standardında kullanıcıya sunulması için dönüştürme, temizleme, belirli ögelerin ortaya çıkarılması için netleştirme sağlanmıştır. Bulut depolamada farklı versiyonların dağıtık olarak saklanarak, bilgi güvenliği ve veri erişim performansı üzerinde araştırma yapılması da planlanmıştır.

Çalışmaya konu olan değerli fotoğraflar gibi bazı nadir nitelikteki eserlerin tarayıcılarla dijitalleştirilmesi uygun olmadığından yüksek teknoloji ürünü fotoğraf makinası stüdyosu tesis edilmiştir. "Çünkü;

$\checkmark$ Hassas ve kırılgan yapıdaki eserler tarayıcılarla dijitalleştirilmeye uygun değildir.

$\checkmark$ Hasarlı ve kapakları rahat açılamayan kitaplar tarayıcıda çekilirse, 180 dereceye kadar açmaya zorlayacağından eserde hasar oluşma riski vardır.

$\checkmark$ Kitap ortasının bombe oluşu sebebiyle tarayıcı cam kapağına tam temas etmeyeceğinden netlik problemleri yaşanmaktadır.

$\checkmark$ Tarayıcıdaki alan derinliği fotoğraf makinesine göre zayıftır.

$\checkmark$ Tarayıcı ile çekilen eser ile elde edilen görüntü renkleri fotoğraf makinesi renklerine göre daha soluk ve cansizdır. Fotoğraf makinesinin görüntüleri orijinaline en yakın kaliteyi verir.

$\checkmark$ Tarayıcılar daha çok dijital arşiv oluşturmak için uygundur. Fotoğraf makinesi (orta format teknik kamera) daha iyi ışık performansı sağlaması, daha yüksek alan derinliği sağlaması, daha yüksek dinamik aralık sağlaması ve yüksek çözünürlüğe imkân tanıması sebebiyle özellikle müze eserleri (kitap, fotoğraf, obje) için ideal performans sağlar. Elde edilen görüntüler tıpkı basım (röprodüksiyon) kalitesindedir" (Bezirci, 2020, s.95). 
"Reprodüksiyon masasının özelliği açılır kapanır hidrolik kapaklı camlı sistem olmasıdır. Cam özel bir cam olup zararlı UV ışınlarına karşı fotoğraflanacak eserleri \%99 koruma sağlayan, \%97 ışık geçirgenliğine, en yüksek parlaklık ve kontrasta sahip gerçek renk iletiminde gözle görülebilir fark yaratan nano teknoloji ithal bir camdır.

Fotoğraf makinesi orta format diye sinıflanan yüksek teknoloji ürünü 60 megapiksel bir kameradır. Kamera görüntü çıktı boyutları ham data $8984 x 7732$ piksel olarak Raw formatta sıkıştırmalı 80MB, sikıştırmasız 60,5 mega piksel TIFF Formatta 200-300 Mb, Jpeg Formatta 20 MB fotoğraf üretmektedir. Kamera da takıl prime lens diye tabir edilen zoom olmayan $80 \mathrm{~mm}$ ve $120 \mathrm{~mm}$ objektifler kullanılmıştır. Eserlerin görüntülenmesinde kamera direkt olarak bir bilgisayara USB 3.0-Fireweri 800 kablo ile bağlanıp çekimler bilgisayar üzerinden kontrollü bir şekilde gerçekleştirilmiştir.

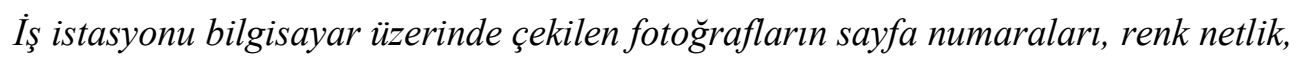
beyaz dengeleri, sayfa boşlukları, kenar biyeleri tek tek kontrol edilmiştir. Her şey bir sıra dahilinde orijinal kaynağa göre ayarlanmıştır. Editör tarafindan çekilen görüntüler onaylandıktan sonra 3 farklı formatta görüntü çıktıları alınıp network sisteminden yedekleme ünitelerine ve bulut teknolojisine aktarllarak yedeklenmiştir" (Bezirci, 2020, s.159-163).

Tanıma, etiketleme ve kataloglama: Fotoğraf albümlerinin ilk kataloğu, Prof. Dr. Nurhan Atasoy'un girişimleri ve desteği ile kurulan, Dr. Erol Pakin, Hüsamettin Aksu, Nihat Ergin ve Nur Taviloğlu'ndan oluşan bir ekip ve bir grup öğrenci tarafından hazırlanmıştır. 1982 yılında başlayan ve yaklaşık beş yıl süren bu çalışma Atasoy'a göre tarihi bir süreçtir. Katalogda fotoğrafçının adı, çekim tarihi, fotoğraf adedi, albüm cildinin özelliği gibi bilgilere yer verilmiştir (Atasoy, 2009, s.2223; Atasoy, 2007, s.8-9).

Sultan II. Abdülhamid Han Fotoğraf Albümleri Projesi kapsamında, fotoğraflarda yer alan her tür detay azami ölçüde tanımlanmış, olası tüm arama kriterleri ile bulunabilir üst düzey nitelikte bibliyografik künyeleri hazırlanmıştır. Kataloglama, bibliyografik künye çalışmaları, Milli Saraylar tarafindan görevlendirilen tarih ve sanat tarihi uzmanı personel ve İstanbul Üniversitesi Kütüphane ve Dokümantasyon Daire Başkanlığı'nda görevli kataloglama uzmanı olan kütüphaneciler tarafindan yapılmıştır (Bezirci, 2020, s.163). İ̈̈ Kütüphaneleri tarafından kullanılan Entegre Kütüphane Otomasyon Sisteminde yapılan, bibliyografik veri girişi işlemleri AAKK2 (Anglo Amerikan Kataloglama Kuralları 2) ve MARC21 (Machine-Readable Cataloging) standartlarına göre düzenlenmiştir. Sinıflama ve kataloglama, fotoğraflara kolay erişim sağlayan önemli bir adımdır, indeksleme düzgün yapılmadıysa, fotoğrafları bir havuzda bulmak imkânsızdır (Şentürk, 2013, s.624). Bu yüzden kataloglama çalışmaları âzami dikkatle yapılmıştır ve albümlerin tanımlama alanları kaydedilirken; albüm no., albümün adı, oluşturulma tarihi, fiziksel özellikleri, cilt bilgileri, albümün içindeki fotoğraf sayısı, albümün ilişkili olduğu diğer albümler, albüm hakkında özel notlar, albümü oluşturan stüdyo, albüm konusu ve albüme ilişkin diğer bilgiler tespit edilerek otomasyon sistemine girilmiştir.

Ayrıca, her bir fotoğraf tek tek incelenerek her bir fotoğraf için de ayrı ayrı tanımlama alanı oluşturulmuştur. Fotoğrafların künyelerinin oluşturulması işlemleri sırasında; tür bilgisi, şekil bilgisi, çekildiği tarih (biliniyorsa), birliktelik kodu, erişim bilgisi, sınıflama bilgisi, fotoğrafın adı (varsa, biliniyorsa), fotoğrafı çeken kişi, fotoğrafin yer/mevki bilgisi, fotoğrafta geçen ilgili kişiler, stüdyo ismi, stüdyo numarası, boyutlar, notlar alanı, koleksiyon bilgisi, fotoğraf konusu ögeleri tespit edilerek otomasyon sistemine girilmiştir.

Sorgulama ve erişim: "Proje hazırlık sürecinde; sunucu ve veri depolama ünitesi ile tarayıcı ve iş istasyonlarının belirlenmesi, iş süreçleri ve görev tanımları oluşturulması sağlanmış, dijital çekim ve kontrol kriterleri, kataloglama işlemleri kontrol kriterleri, tarayıcı/fotoğraf makinesi ve iş istasyonu bakım-kullanım talimatları belirlenmiştir. 
Ayrıca, sunucu ve veri depolama ünitesinin belirlenmesi aşamasında; yürütülmekte olan sayısallaşstırma çalışmalarında üretilen görüntü sayıları ve gelecekte üretilecek olan görüntü sayılarl dikkate alınarak, veri depolama ünitesinin kapasitesi ve üretilen görüntülerin intranet ve/veya internet üzerinde erişime açılabilmesi için gerekli olan sunucu özellikleri hakkında Bilgi İşlem Daire Başkanlığı ile koordineli çalışmalar yapılmıştır. Bilgi Işslem Daire Başkanlığında mevcut sistem alt yapısının özellikleri de dikkate alınarak NetApp Veri Depolama Ünitesi ve sanallaştırılmış sunucular devreye alınmıştır. 450 TB. kapasiteli iki ayrt data merkezinde senkronize olarak yedekleme yapılmaktadır. İstanbul Üniversitesi Bulut Hizmet Düzeyi Sözleşmesi için ihtiyaçlar dikkate alınarak gerekli sanal sunucuların veri depolama alanlar belirlenmiştir. Saylsallaştırılan verilerin Ï̈̈ Bulut Sistemine gönderilmesi için Nadir Eserler Kütüphane binasında mevcut internet alt yapısında iyileştirme yapllmıştır. Saniyede yaklaşık 80-100 MB.lık veri İ̈ Bulut Sistemine gönderilmektedir" (Bezirci,2020:93-94).

Geliştirilen içerik-tabanlı erişim sisteminin ziyaretçiler tarafından kullanılacak olan ara yüzünde temel olarak 2 adet öge bulunmaktır: İçeriğe göz atma (browsing), içerik sorgulama (content query). Resim içeriği ve meta veriler kendi içinde hiyerarşik bir yapıda kullanıcıların göz atması için organize edilerek buluttaki Entegre Kütüphane Otomasyon Sisteminde saklanmaktadır. Bir resim ögesi farklı boyutlarda ya da farklı özellikler (feature) üzerinden etiketlenmiştir. Böylece verinin yer-kişi-olay boyutlarında etiketlenmesi ve indekslenmesi sağlanmıştır. Kullanıcılar sisteme göz atarken boyut geçişi ve görüntüleme yönteminin değişmesine imkân tanınmıştır. Anlamsal ilişkileri görsel olarak en iyi şekilde ifade eden görüntüleme teknikleri üzerinde inceleme yapılarak verilerin kullanıcılara mümkün olduğu kadar kolay ve etkin şekilde sunumu sağlanmıştır. Sorgulama hem anahtar kelime tabanlı hem de resim tabanlıdir.

Sultan II. Abdülhamid Han Fotoğraf Albümleri Projesi Sonuçları: "Sultan II. Abdülhamid Han Fotoğraf Albümleri Proje çalışmast iki etapta gerçekleştirilmiştir; birinci etap kapsamında 45.000 kare ve ikinci etap kapsamında ise 30.000 kare görüntü çekimi yapılarak toplam 75 bin kare görüntü elde edilmiştir. Yaklaşık bir yll süren proje sonucunda; işlemleri tamamlanan fotoğraflar elektronik ortamdan, İstanbul Üniversitesi Kütüphanesi web sayfası https://kutuphane.istanbul.edu.tr/tr/content/iu-sanal-kutuphaneleri adresinden erişilebilir hale getirilmiştir. Aşağıdaki foto 10'da yer aldığ gibi, otomasyon sistemi üzerinden arama kriterlerine göre herhangi bir fotoğraf arandı̆̆ında; önce solda görüldüğ̈̈ şekilde fotoğrafin detaylı bibliyografik künye bilgisi ve künye bilgisindeki yayın linkine tıklandı̆̆ında sağda görüldüğ̈̈ gibi fotoğrafin kendisine erişilebilmektedir" (Bezirci, 2020, s.163).

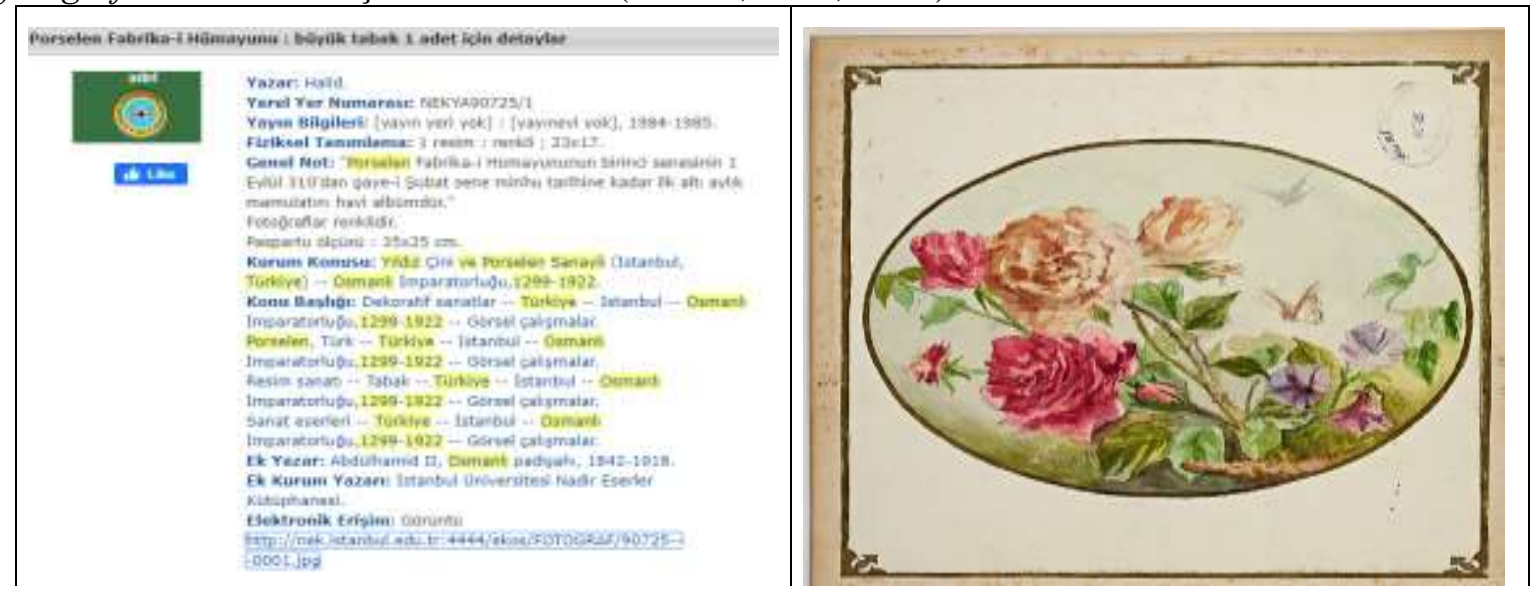

Foto 10. Sultan II. Abdülhamid Han Fotoğraf Albümleri Projesi sonuçlarının yer aldığı Entegre Kütüphane Otomasyon Sisteminden örnek bir ekran görüntüsü. 
"Proje kapsamında dijitalleştirilen fotoğraflar, kullanılan yüksek nitelikli teknolojinin sunduğu imkânlarla yaklaşık iki katı oranında (örneğin $50 X 70 \mathrm{~cm}$. boyutundaki bir fotoğraf yüksek çözünürlüklü ise $100 \times 140 \mathrm{~cm}$.' ye kadar) büyütülebilmekte herhangi bir noktaya odaklanılarak, çıplak gözle görülmeyen yüzlerce ayrıntı bile görülebilmekte, defalarca büyütülse de görüntü kaybı oluşmamaktadır. Fotoğraflara bir fotoğraf sanatçısı, bir sanat tarihçisi gözüyle yaklaşıldığında; bu fotoğrafları çekenin çekimlerini tesadüfen

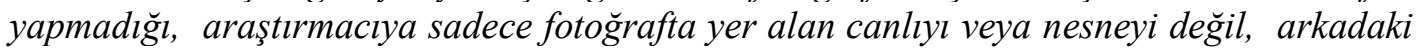
tonlarca detayı da aktardı̆̆ görülmektedir" (Ak, 2020).

"Fotoğraf albümlerinden kamu kurum ve kuruluşları, özel kurum ve kuruluşlar, kültür, siyasi tarih, diş politika, mimarlık, sanat tarihi, fotoğrafçıllk, antropoloji, sosyoloji, eğitim ve mühendislik alanlarında çalışan veya eğitim gören akademisyen ve araştırmacılar ile ögrenciler faydalanmaktadır. Albümlerin dijitalleştirilmesi projesi sonucu oluşan erişim kolaylı $\breve{l}$ sayesinde kullanım ve fayda oranının artacă̆ Üniversitesi Entegre Kütüphane Otomasyon Sistemi üzerinden, Projenin erişime açıldığ ilk aylar olan Mart-Nisan 2020 tarihi verilerine bakıldiğında; 49.572 kişinin sisteme giriş yaptı̆̆ ve albüm kodlart filtresiyle 313.310 adet sayfa fotoğraf görüntülendiğ $i$ görülmektedir. Projenin erişime açıldı̆̆ ilk aylar olduğu dikkate alındığında ilgi, kullanım ve fayda düzeyinin yüksek olduğu anlaşllmaktadır. Ayrıca, İstanbul Üniversitesi ve Kütüphane kurumsal sosyal medya hesaplarında (facebook, twitter, instagram) Projenin, ilk duyurulduğu Nisan 2020 ilk haftasından itibaren ortalama 900-1000 beğeni, paylaşım, görüntüleme oranlarl ve olumlu yorumlar da ilgi ve fayda düzeyinin göstergesidir" (Bezirci, 2020, s.300).

\section{Sonuç ve Değerlendirme}

Fotoğraf, icadından günümüze kadar denetlemeyi mümkün kılacak şekilde gözetleme aracı olarak kullanılmıştır. Fotoğraf da diğer teknolojik gelişmeler gibi, üretildiği dönemin koşulları çerçevesinde, yönetimlerin ve hâkim söylemin ihtiyaçlarına cevap verecek şekilde yönlendirilmiştir. Tespit edici, kanıtlayıcı, sınıflandırıcı araçlar olarak, iktidarın ya da bilimlerin farklı alanlarının hizmetine sunulmuştur. Fotoğraf, kullanım alanı genişledikçe ve işlevi arttıkça, paralel olarak kamusal alanda gittikçe daha profesyonel bir şekilde denetlemeyi kolaylaştıran kayıt ve propaganda malzemelerine dönüşmüştür. Böylece fotoğraflar, 19. yüzyılda filizlenen ve süregelen toplumsal dönüşümlerin göstergesi olarak toplum bilimleri için önemli belgeler ve kaynaklar haline gelmiştir. Fotoğrafik görüntüler, ilerleyen yıllarda toplumsal belleğin inşasında araç olmuşlar ve tarihi olaylara dair görüntüler, vakaları kamuoyu gözünde meşru hale getirmişlerdir.

$\mathrm{Bu}$ bağlamda, fotoğrafin yaygın ve etkin kullanıldığı tarihi bir süreç olan II. Abdülhamid döneminde, fotoğrafın belge, tespit, tanıtım ve iletişim aracı olarak kullanılmaya başlanması ile Yıldız Sarayı Fotoğraf Koleksiyonu oluşmuştur. İktidarda olduğu dönemin teknolojik gelişmelerine açık bir padişah olarak, Sultan II. Abdülhamid Han'ın oluşturduğu fotoğraf arşivi 1800'lü yıllara ait önemli ve değerli bir kültür mirasıdır. 19. yüzyıla ait dünyanın en büyük görsel arşivi olarak tanımlanan, dünyanın çeşitli ülkelerindeki sistemlerin değişmezden önceki son fotoğraflarını toplu halde sunan fotoğrafları günümüze ulaştıran bu albümler, geleceğe yapılacak projeksiyonlar için önemli pencerelerdir. Osmanlı tarihi yanı sıra sosyal, siyasal, coğrafi, sanatsal ve daha pek çok açıdan toplumsal gelişmeleri izleme ve belgelendirme fırsatı sunan, nadir eser niteliğine sahip II.Abdülhamid fotoğraf koleksiyonu yüksek belge değeri ile tarihe 1şık tutmaktadır. Geniş kullanım alanına sahip bu albümler dönemin teknoloji, bilim, sanat ve estetik anlayışı yanı sıra bilgi belge ve arşivcilik faaliyetlerine bakış açısını da göstermektedir.

Bu değerli kaynak eserleri kapsayan Yıldız Sarayı Kütüphanesi koleksiyonu 1924 yılında, M.K. Atatürk'ün emri ile Medrese-t-ül Kuzat (Kadı Okulu) binasında bulunan, bugünkü İstanbul Üniversitesi Nadir Eserler Kütüphanesi olan, Darülfünun Kütüphanesi’ne nakledilmiştir. Halen 
İstanbul Üniversitesi Nadir Eserler Kütüphanesi’nde bulunan II. Abdülhamid Han Albümleri, geçmişten günümüze taşınan bu fotoğrafların bilgi ve belge aracı olarak bugün nasıl kullanıldığının ortaya konulması amacıyla, bu çalışma kapsamında incelenmiş, fotoğraf konuları, nitelikleri ve fotoğrafları kullanan araştırmacı profilleri açısından sayısal verilerle analiz edilmiştir. Bu araştırma sonuçlarına göre; Yıldız Albümleri Koleksiyonundaki fotoğraf konuları, sivil mimariden dini mimariye, resmi binalardan meydanlara, külliyelerden köprülere, kervansaraylardan mekteplere ve hastanelerden yollara kadar çok geniş bir içeriğe sahiptir. Dünyanın çeşitli ülkelerindeki rejim, sistem, sosyal ve siyasal yapıların incelenmesi açısından önemli bir görsel vasıtadır. Fotoğrafların bir kısmı Amerika, Avrupa ile başta Japonya olmak üzere bazı Uzakdoğu ülkelerindeki şehir ve tabiat güzelliklerini, liderleri, sarayları ve çeşitli sanayi ürünlerini, müze ve sanat eserlerini vs. konu olarak almaktadır. Dinler ve medeniyetler tarihi içindeki ehemmiyeti açısından, Osmanlı topraklarının ve bilhassa İstanbul'un, çoğu Avrupalı fotoğraf sanatçısının ilgi odağı olduğu fotoğrafların içerik ve sayılarından anlaşılmaktadır. II. Abdülhamid albüm koleksiyonu fotoğraf sanatı açısından da önemli bir kaynak eserdir. Albümler, fotoğraf sanatçıları yönüyle de dönemin en yetenekli ve ünlü usta fotoğrafçıların bakış açılarını yansıttığı görülmektedir.

Ayrıca, Yıldız Sarayı Fotoğraf Koleksiyonu'nun sadece bir kültür hazinesi olmayıp, birçok farklı alanı (tarih, sanat, mimari, coğrafya, eğitim, edebiyat vd.) ilgilendiren görselleri bünyesinde barındırdığg için farklı bilim ve sanat dalları açısından da önemli bir veri kaynağı olduğu ve çeşitli bilimsel çalışmalara kaynak teşkil ettiği görülmektedir. Albümler farklı yönlerden ele alınmakta, farklı disiplinleri içeren film, belgesel, tıpkı basım (röprodüksiyon), akademik yayın, sergi gibi çeşitli çalışmalar yapılmaktadır.

$\mathrm{Bu}$ değerli fotoğrafların, tarihi birer bellek olarak önemli arşiv malzemesi özellikleri sebebiyle, devamlılıklarını sağlamak stratejik bir önem taşımaktadır. Kanıtsal değere sahip arşiv malzemeleri olan fotoğrafların tanımlanması ve muhafazası elzemdir. Ayrıca, arşiv malzemesi özellikleri ve görsel değerleri bakımından fotoğrafların erişıim koşullarının iyileştirilmesinin de önemli olduğu bu çalışmada öne çıkarılmaktadır. Çalışmada örnek uygulama olarak anlatıldığı üzere, Albüm Koleksiyonunun kondisyon koşullarının muhafazasını sağlayarak, araştırmacıların kullanımına sunmak üzere dijital kopyalarının oluşturulması, araştırmacıların fotoğraflara hızlı ve güvenli bir şekilde erişebilmelerinin sağlanması hedefiyle, II. Abdülhamid Han Yıldız Albümleri Projesi, Cumhurbaşkanlığı himayesinde, İstanbul Üniversitesi Rektörlüğü ve Milli Saraylar işbirliği ile gerçekleştirilmiştir. İstanbul Üniversitesi II. Abdülhamid Fotoğraf Albümleri Projesi kapsamında, değerli fotoğrafların dijitalleştirilmesi, nitelikli bibliyografik künye çalışmalarının yapılması ve elektronik ortamdan erişime açılması yoluyla, tarihi belge niteliğindeki fotoğrafların araştırmacı ile buluşturulması ve bilgi iletişimine katkı sağlandığı görülmektedir.

Kültürel miras değeri olan eserlerin dijital ortama aktarılması ve dijital ortamda kalıcılığının sağlanması içeriği korumak için bir tür sigortadır. Sultan II. Abdülhamid Fotoğraf Albümleri Projesi de bilimsel çalışmalara 1şık olacak nitelikte yeni bir kaynak oluşturmuştur. Bu kıymetli görsel hazinenin dijitalleştirilmesi, bibliyografik künyelerinin yapılması ve elektronik ortamda erişime açılması sonucunda; koleksiyonun gelecek nesillere aktarılması, kültürel miras değerinin korunması ve dijital erişiminin sağlanması yanı sıra dönemin sosyal, kültürel, ekonomik ve siyasi tarihinin fotoğraf koleksiyonu üzerinden okuma, yorumlama ve tespit etme firsatının araştırmacılara zaman ve mekândan bağımsız olarak sunulması sağlanmış, bilimsel çalışmalara katkı ve kolaylık etkisi oluşturulmuştur. 


\section{Kaynakça}

Ak, M. (2020). “II. Abdülhamid Han’ın Yıldız Albümlerinin dijitalleştirilmesi devletimizin ufkunu göstermektedir" https://www.istanbul.edu.tr/tr/haber/prof-dr-ak-ii-abdulhamid-haninyildiz-albumlerinin-dijitallestirilmesi-devletimi.

Amar, P. J. (2009). Basın fotoğrafçıllı̆̆ İnci Çınarlı (çev.), Kırmızı Yayınları.

Arıcan, M. Z. (2007). "Bilgi paylaşım aracı olarak fotoğraf”, Yeni Düşünceler, 2, 421-429.

Atasoy, N. (2007). Yıldız Sarayı Fotoğraf Albümlerinden Yadigar-ı İstanbul, Akkök Yayınları.

Atasoy, N. (2009). "Görsel tarihin tapusu”, Sultan II. Abdülhamid'in aile albümü, Hakan Y1lmaz (Ed.), İstanbul Büyükş̧ehir Belediyesi.

Atasoy, N. (2015). "Yıldız Sarayı Kütüphanesi”, Yıldız Sarayı'ndan İstanbul Üniversitesi’ne, Lale Uluç (Ed.), İstanbul Üniversitesi.

Ballenger, H. B. (2014). Photography: a communication tool, Master Thesis, Georgia: State University.

Bayhan, N. (2009). Sultan II. Abdülhamid'in aile albümü, İstanbul Büyükşsehir Belediyesi Kültür A.Ş. Yayınları.

Bezirci, P. (2019). "From Y1ldı Palace Library collection with examples; language policies and language education in the period of Sultan Abdülhamid II.", Foreign Language Teaching, 46/3, 275-287.

Bezirci, P. (2020). “Teknolojinin tarihle buluşması: Yıldız Sarayı Fotoğraf Albümleri”, I Ĭgdır Üniversitesi Sosyal Bilimler Dergisi, 22, 283-304.

Bezirci, P. (2020). Geçmişten geleceğe açılan kapı: İstanbul Üniversitesi Merkez Kütüphanesi: 2012-2020, Hiperyayın.

Çiçek, E. (2018). "Sihirli belge fotoğrafın osmanlı devletinde kabulü, gelişimi ve II. Abdülhamid Dönemi”, International Social Sciences Studies Journal, 4(23):4581-4589. https://doi.org/10.26449/sssj.822

Dördüncü, M. B. (2006). II. Abdülhamid Yıldız Albümleri Mekke-Medine, Salih Gülen ve Fatih Akçe (Ed.). Yitik Hazine Yayınları.

Gezgin, S. (1994). Basında Fotoğrafçılık, Der Yayınları.

Greene, T. (2010). "The Abdülhamid II Photo Collection: orientalism and public 1mage at the end of an empire", https://www.semanticscholar.org/paper/The-Abdu\%CC\%881hamid-II-PhotoCollection\%3A-Orientalism-at-Greene/2f34139ae9ab36dffec63c651dab59eb41d3fa92.

Kocaışık, D. V. \& Uslu, S.S. (2015). “Sultan II. Abdülhamid Albümleri'nin Yıldız Sarayı ve yapıları ekseninde incelenmesi", II.Uluslararası güzel sanatlar bilimsel araştırma günleri, Özlem Özaltunoğlu (Ed.), Cumhuriyet Üniversitesi Yayınları.

Mardin, Ş. (1985). “19.yy'da düşünce akımları ve Osmanlı Devleti”. Tanzimat'tan Cumhuriyet'e Türkiye Ansiklopedisi, 2. Cilt. İletişim Yayınları, 342-351.

Ozanne, J. \& Moscato E., Kunkel D. (2013). "Transformative photography: evaluation and best practices for eliciting social and policy changes", Journal of Public Policy \& Marketing, 32 (1). https://doi.org/10.1509/jppm.11.161

Satkın, M. B. (2014). "Fotoğraf, gerçeklik ve algı", Sanat - Tasarım Dergisi, 5, 7-13. 
Şenalp, L. (1998). İstanbul Üniversitesi Merkez Kütüphanesi :başlangıcından günümüze. Türk Kütüphaneciler Derneği.

Şentürk, B. (2013). "Photographs as archival material”, Türk Kütüphaneciliği, 27, 4, 619-632.

Toksoy, N. G. (2019). "Fotoğraf aslında neyin belgesi? fotoğrafin toplumsallığı ve medya ve gerçeklik tartışmalarında değişmeyen rolü”, Mediterranean Journal of Humanities, IX/2, 491-505. https://doi.org/10.13114/MJH.2019.504

Türköne, M. \& Önder, T. (2011). Şerif Mardin bütün eserleri 9, Türk modernleşmesi makaleler 4, İletişim Yayınları.

Waley, M. I. (1991). "Images of The Ottoman Empire: The photograph albüms presented by Sultan Abdülhamid II", The British Library Journal, Vol. 17, No. 2, 111-127.

Yılmaz, H. (2009). Sultan II. Abdülhamid Arşivi İstanbul fotoğrafları, İstanbul Büyükşehir Belediyesi Kültür A.Ş. Yayınları.

Yılmaz, H. (2011). Sultan II. Abdülhamid'in arşivinden dünya liderleri, İstanbul Büyükșehir Belediyesi Kültür A.Ş. Yayınları. 